\title{
Spatiotemporal responses in crop water footprint and benchmark under different irrigation techniques to climate change scenarios in China
}

Zhiwei Yue ${ }^{1,3, *}$ Xiangxiang Ji ${ }^{1,3, *}$, La Zhuo ${ }^{2,3,4,5}$, Wei Wang ${ }^{4,5}$, Zhibin Li $^{4,5}$, Pute $\mathrm{Wu}^{2,3,4,5}$

$5 \quad{ }^{1}$ College of Water Resources and Architectural Engineering, Northwest A\&F University, Yangling 712100, China

${ }^{2}$ Institute of Soil and Water Conservation, Northwest A\&F University, Yangling 712100, China

${ }^{3}$ Institute of Water-saving Agriculture in Arid Regions of China, Northwest A\&F University, Yangling 712100, China

${ }^{4}$ Institute of Soil and Water Conservation, Chinese Academy of Sciences and Ministry of Water Resources, Yangling 712100, China

$10 \quad{ }^{5}$ University of Chinese Academy of Sciences, Beijing 100049, China.

*These authors contributed equally to this work.

Correspondence to: La Zhuo (zhuola@nwafu.edu.cn; 1zhuo@ms.iswc.ac.cn ) and Pute Wu (gjzwpt@hotmail.com )

Abstract. Adaptation to future climate change with limited water resources is a major global challenge to sustainable and

15 sufficient crop production. However, the large-scale responses of crop water footprint and its associated benchmarks under various irrigation techniques to future climate change scenarios remain unclear. The present study quantified the responses of maize and wheat water footprint per unit yield (WFP, $\mathrm{m}^{3} \mathrm{t}^{-1}$ ) and corresponding WFP benchmarks under two representative concentration pathways (RCPs) in the 2030s, 2050s, and 2080s at a 5-arc minute grid level in the case for China. The differences among rain-fed and furrow-, micro-, and sprinkler-irrigated wheat and maize were identified. Compared with the baseline year (2013), maize WFP will increase under both RCP2.6 and RCP8.5, by $17 \%$ and $13 \%$, respectively, until the 2080s. Wheat WFP will increase under RCP2.6 (by $12 \%$ until the 2080s), while decrease by $12 \%$ under RCP8.5 until the 2080s. WFP will increase the most for rain-fed crops. Relative to rain-fed crops, micro irrigation and sprinkler irrigation result in the smallest increases in WFP for maize and wheat, respectively. These water-saving managements will more effectively mitigate the negative impact of climate change. Furthermore, the spatial distributions of WFP benchmarks will not change as dramatically as those of WFP. The present study demonstrated that the visible different responses to climate change in terms of crop water consumption, water use efficiency, and WFP benchmarks under different irrigation techniques must be addressed and monitored. It also lays the foundation for future investigations into the influences of irrigation methods, RCPs, and crop types on WFP and its benchmarks in response to climate change in all agricultural regions worldwide. 


\section{Introduction}

The progressive decline in water resource availability is a major impediment to global food production security (Pastor et al., 2019; Trnka et al., 2019; Konapala et al., 2020). Food crops are the main source of human nutrition (Myers et al., 2017; Lobell and Gourdji, 2012). Humans depend on food crops for $\sim 47 \%$ of their daily protein intake (FAO, 2021). As a result of human activity, however, the climate system is changing and global warming is a significant characteristic of this process (IPCC, 2021). Global mean temperatures have increased with each successive decade since 1850 (Kappelle, 2020). Climate change affects water consumption and crop yield by altering precipitation, temperature, carbon dioxide $\left(\mathrm{CO}_{2}\right)$ concentration, and other factors during crop growth (Hatfield and Dold, 2019). Crop adaptation to future climate change with limited water resources has become a major challenge in sustainable crop production and supply worldwide.

The water footprint per unit crop (WFP, $\mathrm{m}^{3} \mathrm{t}^{-1}$ ) (Hoekstra, 2003) is the amount of water consumed by the crop per unit

40 yield during crop growth within a certain region. It includes blue WFP (surface and groundwater), green WFP (precipitation that will not become runoff), and grey WFP (freshwater that needed to assimilate pollutants from human activities) (Hoekstra et al., 2011). Blue and green WFP are collectively known as consumptive WFP. Grey WFP is also called degradative WFP (Hoekstra, 2013). Unlike traditional crop water productivity and other agricultural water metrics, WFP covers water consumption, sources, and spatiotemporal dimensions during the crop growth period. In this way, water consumption intensity and efficiency for irrigated and rain-fed planting modes may be compared. WFP is an effective indicator of the sustainability of regional water use and optimal water resource allocation (Xu et al., 2019; Mali et al., 2021). The present study focuses exclusively on consumptive WFP which depends on crop yield and the intensity of water consumption per unit planted area.

There are several studies conducted on the responses of WFP to future climate change. Nevertheless, no consensus has been reached. Certain scholars believe that future climate change will weaken food crop production security. Ahmadi et al.

50 (2021) reported that maize WFP in the Qazvin Plain of India will increase by $42 \%$ and $147 \%$ under representative concentration pathways (RCP) 4.5 and RCP8.5, respectively, by 2061-2080. Zheng et al. (2020) found that rice yield in Henan and Jiangsu (China) will decrease while WFP will increase under four RCPs at various stages of the $21^{\text {st }}$ century. Other scholars believe that crop yield may actually benefit from future increases in precipitation and atmospheric $\mathrm{CO}_{2}$ concentration. Jans et al. (2021) considered the combined effects of changes in climatic factors such as temperature and precipitation as well as rising atmospheric $\mathrm{CO}_{2}$ concentration and predicted that between 2011 and 2099, global cotton yield will increase by $>50 \%$ and WFP will decrease by $30 \%$ under RCP8.5. Arunrat et al. (2020) found that in the present century, the yield of individual and large-scale rice farms in Thailand will increase by 1-30\% and 2-31\%, respectively, while WFP will decrease by 10-43\% and 1-67\%, respectively, under RCP4.5. Significant spatiotemporal differences in WFP under various irrigation techniques have been confirmed at the site (Chukalla et al., 2015) and regional (Wang et al., 2019) scales. However, current large-scale studies on the responses of WFP to environmental change are usually based on simulations assuming adequate furrow irrigation. These studies exclude comparisons between various irrigation techniques and the differences in their influences on crop WFPs. 
Although Dai et al. (2020) optimised maize and wheat cropping patterns under RCP4.5 and RCP8.5 with consideration of various irrigation modes in the case for the Huaihe River Basin of China by 2050, they only considered blue water.

Magnitudes and constitution of crop WFP varies widely among regions and areas (Mekonnen and Hoekstra, 2011). To encourage water users to reduce WFP to a reasonable level, Hoekstra $(2013,2014)$ recommended establishing WFP benchmarks for different products as they facilitate prudent water allocation and fair water resource sharing among sectors and users (Hoekstra, 2013). On the large-scale, specific WFP benchmarks can be set for crops grown on different farms within the same region (Mekonnen and Hoekstra, 2014). A previous study demonstrated the sensitivity of WFP benchmarks to climate zones (Zhuo et al., 2016a). WFP benchmarks significantly differ among irrigation techniques, especially in arid zones (Wang

70 et al., 2019). However, little is known about the responses of WFP benchmarks under different irrigation techniques to future climate change.

To probe into the influence of future climate change on large-scale WFP and benchmarks under diverse irrigation techniques, the research cases used here were maize and wheat grown in mainland China. We used the outputs of six global climate models (GCMs) (Table 1), including three models each for relatively wet and dry climate outputs, in Coupled Model

75 Intercomparison Project Phase 5 (CMIP5). We then used the AquaCrop model to simulate the spatiotemporal responses of blue and green WFP and corresponding WFP benchmarks for wheat and maize in the 2030s (2020-2049), 2050s (2040-2069), and 2080s (2070-2099) under RCP2.6 and RCP8.5 at a 5-arc minute grid resolution. We distinguished between rain-fed and irrigated planting modes and among furrow, micro, and sprinkler irrigation.

As of 2019, China was the world's second largest maize and largest wheat producer, accounting for $23 \%$ and $17 \%$ of 80 total global production, respectively (FAO, 2021). China's cereal production has helped stabilise global food production and supply. In 2019, the planted areas of maize and wheat in China were 41 million ha and 24 million ha, respectively, and accounted for $25 \%$ and $14 \%$ of the national total croplands, respectively (NBSC, 2021). Cereal production consumes substantial volumes of water in China and these quantities change over time. Zhuo et al. (2019) reported that maize water consumption increased by $49 \%$ between 2000 and 2013 as planted areas and feed demand increased. By contrast, Wang et al.

85 (2019) reported that wheat planted and irrigated areas decreased and water consumption slightly declined (4.4\%) from 2000 to 2014. Other studies reported that maize and wheat consume relatively more water in the North than the South of China (Tian et al., 2019; Wang et al., 2019). Therefore, the water consumption rates of these staple crops under future climate change scenarios should be closely monitored to ensure water supply and food crop production security in China and worldwide. Compared with existing researches, the innovations of our research are embodied in two points. The present study firstly

90 clarifies large-scale spatiotemporal responses of WFP to future climate change scenarios under different irrigation techniques. It is also the first to explore large-scale changes in WFP benchmarks under future climate change scenarios.

Table 1. Inventory of global climate models (GCMs) used in the current study.

\begin{tabular}{lll}
\hline GCM & Institute & Reference \\
\hline
\end{tabular}




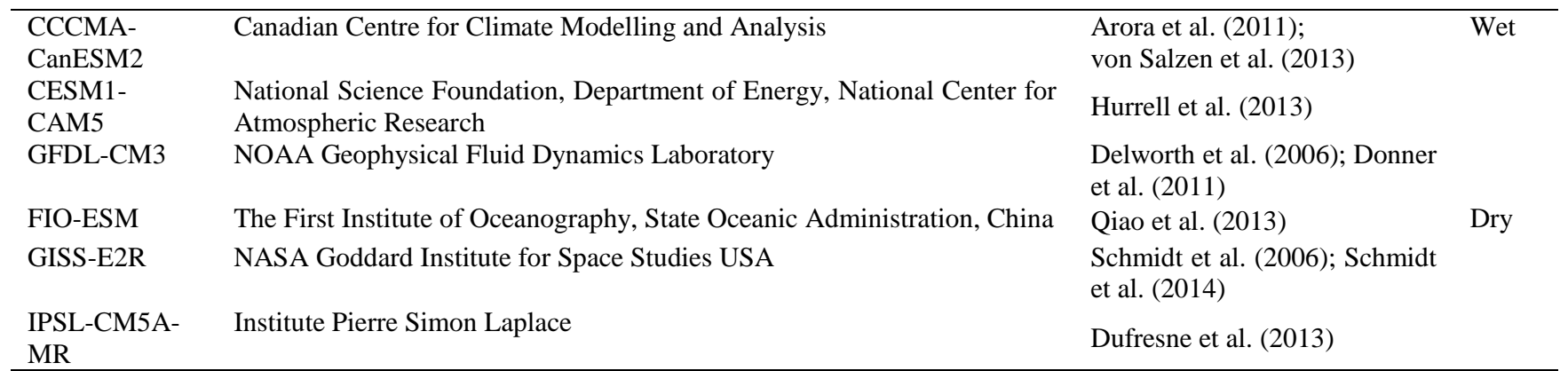

\section{Method and data}

\subsection{Determining the baseline year}

Annual reference evapotranspiration $\left(\mathrm{ET}_{0}, \mathrm{~mm}\right)$ and precipitation $(\mathrm{PR}, \mathrm{mm})$ in China were calculated (Harris et al., 2014). Thence, the aridity index (AI) was calculated and climate change trends from 2000 to 2014 were analysed. The year 2013 was designated the baseline as its drought level was nearest the 15-year national average. The AI was calculated according to the method of Middleton and Thomas (1997):

$$
A I=\frac{P R}{E T_{0}},
$$

\subsection{Water footprint per unit crop calculation}

WFP $\left(\mathrm{m}^{3} \mathrm{t}^{-1}\right)$ comprises blue WFP $\left(\mathrm{WFP}_{\mathrm{b}}, \mathrm{m}^{3} \mathrm{t}^{-1}\right)$ and green WFP $\left(\mathrm{WFP}_{\mathrm{g}}, \mathrm{m}^{3} \mathrm{t}^{-1}\right)$ :

$$
W F P=W F P_{b}+W F P_{g},
$$

where $W F P_{b}$ and $W F P_{g}$ were calculated as the quotient of the blue $\left(\mathrm{CWU}_{\mathrm{b}}, \mathrm{m}^{3} \mathrm{ha}^{-1}\right)$ and green $\left(\mathrm{CWU}_{\mathrm{g}}, \mathrm{m}^{3} \mathrm{ha}^{-1}\right)$ components of crop water use $\left(\mathrm{CWU}, \mathrm{m}^{3} \mathrm{ha}^{-1}\right)$ and crop yield $\left(\mathrm{Y}, \mathrm{t} \mathrm{ha}^{-1}\right)$, respectively. $\mathrm{CWU}_{\mathrm{b}}$ and $\mathrm{CWU}_{\mathrm{g}}$ were equivalent to the cumulation of daily evapotranspiration (ET, $\mathrm{mm} \mathrm{d}^{-1}$ ) throughout the whole crop growth period (Hoekstra et al., 2011):

$$
\begin{aligned}
& W F P_{b}=\frac{C W U_{b}}{Y}=\frac{10 \times \sum_{d=1}^{l g p} E T_{b}}{Y}, \\
& W F P_{g}=\frac{C W U_{g}}{Y}=\frac{10 \times \sum_{d=1}^{l g p} E T_{g}}{Y},
\end{aligned}
$$

where $E T_{b}$ and $E T_{g}(\mathrm{~mm})$ refer to the blue and green water evapotranspiration, respectively, and lgp refers to the number of days of the crop growth period. The coefficient 10 is a unit conversion factor, transforming the water depth of ET (mm) into the water amount per unit land area of CWU $\left(\mathrm{m}^{3} \mathrm{ha}^{-1}\right)$.

The ET and Y per grid for each crop were simulated by AquaCrop model based on the dynamic daily soil water balance (Mekonnen and Hoekstra, 2010): 
$S_{[t]}=S_{[t-1]}+P R_{[t]}+I R R_{[t]}+C R_{[t]}-E T_{[t]}-R O_{[t]}-D P_{[t]}$,

where $S_{[t]}$ and $S_{[t-1]}(\mathrm{mm})$ refer to the water content in soil when the day t ends and begins, respectively, $P R_{[t]}(\mathrm{mm})$ is the amount of precipitation on day $\mathrm{t}, I R R_{[t]}(\mathrm{mm})$ is the amount of water used for irrigation, $C R_{[t]}(\mathrm{mm})$ is the capillary rise to the crop root zone from the shallow groundwater, $R O_{[t]}(\mathrm{mm})$ is the water lost by surface runoff due to precipitation, and $D P_{[t]}$ $(\mathrm{mm})$ is the water lost by deep percolation caused by excessive precipitation or irrigation. It was assumed that $C R_{[t]}=0$ as the

115 ground water depth was $\gg 1 \mathrm{~m}$ (Allen et al., 1998). $R O_{[t]}$ was calculated using the Soil Conservation Service curve-number (CN) equation (USDA, 1964; Rallison, 1980):

$$
\begin{aligned}
& R O_{[t]}=\frac{\left(P R_{[t]}-I_{a}\right)^{2}}{P R_{[t]}+S-I_{a}}, \\
& S=254\left(\frac{100}{C N}-1\right),
\end{aligned}
$$

where $S(\mathrm{~mm})$ is the potential maximum water storage, $I_{a}(\mathrm{~mm})$ is the initial amount of water loss before the runoff formation.

By tracking the daily flow of water in and out of the crop root zone, we separated the daily blue and green soil water balances (Zhuo et al., 2016b):

$$
\begin{aligned}
& S_{b[t]}=S_{b[t-1]}+\left(P R_{[t]}+I R R_{[t]}-R O_{[t]}\right) \times \frac{I R R_{[t]}}{P R_{[t]}+I R R_{[t]}}-\left(D P_{[t]}+E T_{[t]}\right) \times \frac{S_{b[t-l]}}{S_{[t-l]}}, \\
& S_{g[t]}=S_{g[t-1]}+\left(P R_{[t]}+I R R_{[t]}-R O_{[t]}\right) \times \frac{P R_{[t]}}{P R_{[t]}+I R R_{[t]}}-\left(D P_{[t]}+E T_{[t]}\right) \times \frac{S_{g[t-1]}}{S_{[t-l]}},
\end{aligned}
$$

where $S_{b[t]}$ and $S_{b[t-l]}(\mathrm{mm})$ are the blue water content in soil when the day t ends and begins, respectively, and $S_{g[t]}$ and $S_{g[t-1]}$ $(\mathrm{mm})$ are the green water content in soil when the day t ends and begins, respectively. It is assumed that the initial soil water content before the crop growth period is green water.

In AquaCrop, the daily transpiration $\left(\operatorname{Tr}_{[\mathrm{t}}, \mathrm{mm}\right)$ calculates the daily shoot biomass production $(\mathrm{B}, \mathrm{kg})$ using the normalised crop biomass water productivity (WP* $\mathrm{kg} \mathrm{m}^{-2}$ ) (Raes et al., 2017):

$$
B=W P^{*} \times \sum \frac{\operatorname{Tr}_{[t]}}{E T_{0[t]}}
$$

125 where $W P^{*}$ is normalised to consider $\mathrm{CO}_{2}$ concentration, reference evapotranspiration $\left(\mathrm{ET}_{0}\right)$, and crop classes $(\mathrm{C} 3$ or $\mathrm{C} 4)$ so that it is applicable to various locations and seasons. Water productivity remains constant for specific crops. $\mathrm{Y}$ as the harvestable portion of final B is calculated by multiplying B with the adjusted reference Harvest Index $\left(\mathrm{HI}_{0}, \%\right)$ :

$$
Y=f_{H I} \times H I_{0} \times B,
$$

where $f_{H I}$ is a correction factor for $H I_{0}$. It considers the water and temperature stresses during the crop growth period. The simulated Y per grid for each crop in 2013 was validated via scaling model simulation outputs to accord with the crop yield statistics data at the provincial level (NBSC, 2021), following Zhuo et al. (2016c) and Mialyk et al. (2021).

\subsection{Benchmarking consumptive WFP in crop production}

Based on the work of Mekonnen and Hoekstra (2014), we ranked grid-level WFP for each crop in ascending order of size against the corresponding accumulative percentages of the total crop production. The annual WFP of $20 \%$ or $25 \%$ of the 
producers with the highest water productivity in China was set as the annual WFP benchmark. The climate zones should be divided when WFP benchmarks were established (Zhuo et al., 2016a). To this end, the aridity index (AI) partitioned China into arid $(<0.5)$ and humid $(>0.5)$ zones based on the annual $\mathrm{ET}_{0}$ and PR from 2000 to 2014 at a 30-arc minute grid resolution (Harris et al., 2014) (Fig. 1).

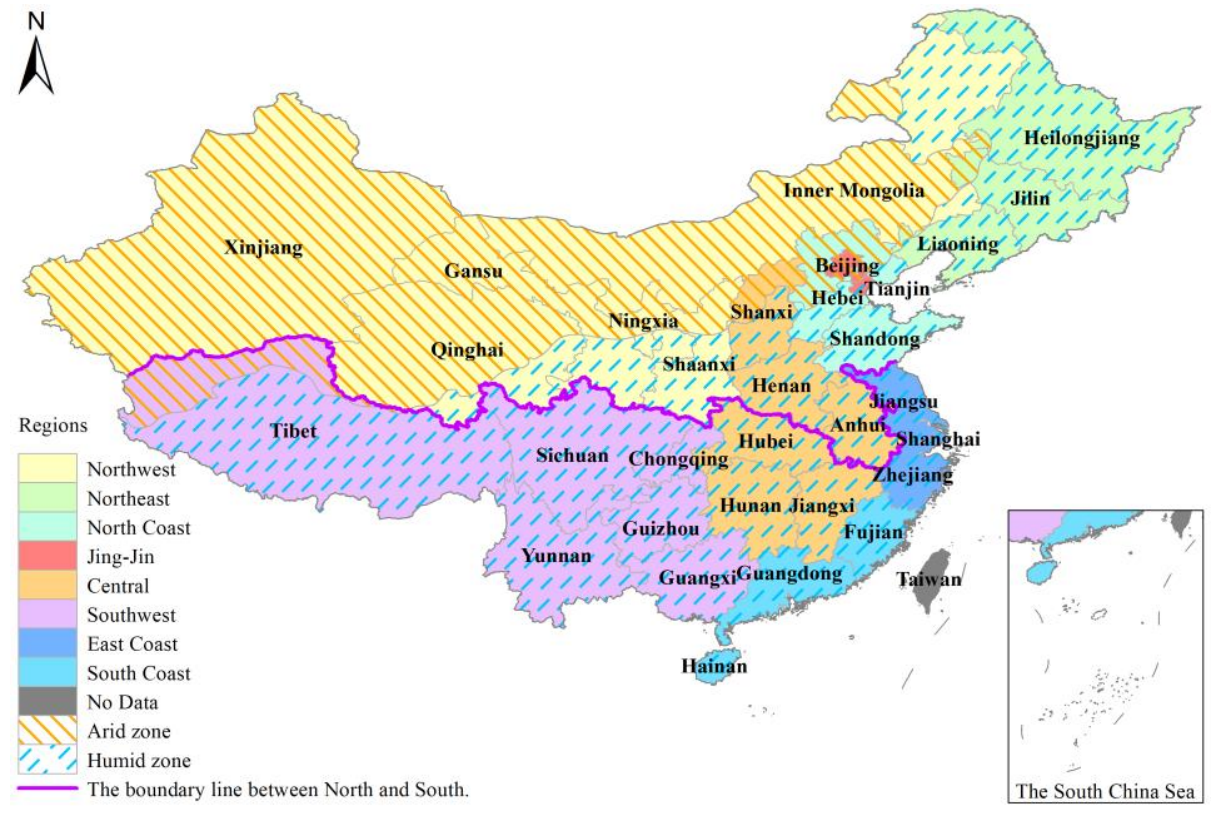

Figure 1. Regions and climate zones of mainland China.

\subsection{Data sources}

Monthly climate data such as maximum (Tx), minimum air temperature (Tn), precipitation (PR) and reference evapotranspiration $\left(\mathrm{ET}_{0}\right)$ from 2000 to 2014 at a resolution of 30-arc minute were derived from the CRU-TS 3.24 dataset (Harris et al., 2014; CEDA, 2018). The mean annual atmospheric $\mathrm{CO}_{2}$ concentration (ppm) from 2000 to 2014 was obtained

145 from the Mauna Loa Observatory, Hawaii, USA (NOAA, 2018). The downscaled outputs of six GCMs at a 5 -arc minute grid resolution in the 2030s, 2050s, and 2080s were obtained from the Climate Change, Agriculture and Food Security (CCAFS) database (Navarro-Racines et al., 2020; CCAFS, 2015). As the CCAFS database has not $\mathrm{ET}_{0}$ data, we calculated $\mathrm{ET}_{0}$ for each climate scenario using temperature inputs and the Penman-Monteith method (Allen et al., 1998). The projected $\mathrm{CO}_{2}$ concentrations under RCP2.6 and RCP8.5 were obtained from van Vuuren et al. (2007) and Riahi et al. (2007), respectively.

150 The selected maximum root depth (Zx) and Harvest Index (HI) in AquaCrop were derived from Allan et al. (1998). And the other parameters used in AquaCrop were derived from Raes et al. (2017). Soil texture data and soil water capacity data at a 5arc minute grid resolution were acquired from the ISRIC Soil and Terrain database (Dijkshoorn et al., 2008) and ISRIC-WISE dataset (Batjes, 2012), respectively. The planted areas for each irrigated or rain-fed crop at a 5-arc minute grid resolution were 
acquired from the MIRCA2000 dataset (Portmann et al., 2010). We divided these planted areas into different parts subjected to various irrigation techniques using statistical yearbook data (NBSC, 2021). Provincial-level crop yield statistics data were procured from the National Bureau of Statistics of China (NBSC, 2021).

\section{Results}

\subsection{Future climate change trends in maize and wheat planted areas}

In the baseline year 2013, the average annual reference evapotranspiration $\left(\mathrm{ET}_{0}\right)$ and precipitation $(\mathrm{PR})$ in the planted areas of two crops were $941 \mathrm{~mm}$ and $727 \mathrm{~mm}$, respectively. Compared with the baseline level of 2013, the average annual ET 0 and PR in the planted areas of two crops will both increase under two RCPs. The increase in $\mathrm{ET}_{0}$ exceeds that of PR. ET 0 will increase by $17 \%$ and $29 \%$ under RCP2.6 and RCP8.5, respectively, until the 2080s. However, PR will increase by $8 \%$ and $14 \%$, respectively. The increases under RCP8.5 (18-29\% and 3-14\% for $\mathrm{ET}_{0}$ and PR, respectively) are much higher than those under RCP2.6 (16-17\% and 4-8 \% for $\mathrm{ET}_{0}$ and PR, respectively). Climate change will be relatively more intense under RCP8.5. The increases in $\mathrm{ET}_{0}$ are concentrated from April to August (14-39 mm). The increases in PR increases are concentrated between June and August (8-20 mm and 12-28 mm, respectively). However, PR will decline in May, July, November, and December while PR will decline more in May ( $\leq 9 \mathrm{~mm}$ until the 2030s) (Fig. 2a, b). Water and heat resources were unevenly distributed in the planted areas of the two crops in 2013. $\mathrm{ET}_{0}$ was relatively higher in East Coast and North China. PR distribution was comparatively higher in the South and lower in the North (Fig. S4). Compared with 2013, $\mathrm{ET}_{0}$ and PR for the most heavily planted areas will increase under both scenarios until the 2080s. The areas with relatively greater increase in $\mathrm{ET}_{0}$ are distributed mainly in Southwest and Northeast (Fig. 2c, e). PR increases relatively faster in Northwest and Jing-Jin (Fig. 2d, f). ET 0 decreases mainly in Xinjiang and Inner Mongolia (Fig. 2c, e). PR decreases mainly in Xinjiang, Tibet, Northeast, and South Coast (Fig. 2d, f). However, the areas wherein $\mathrm{ET}_{0}$ falls are 86-94\% smaller than those wherein PR declines. 
(a) Monthly ET
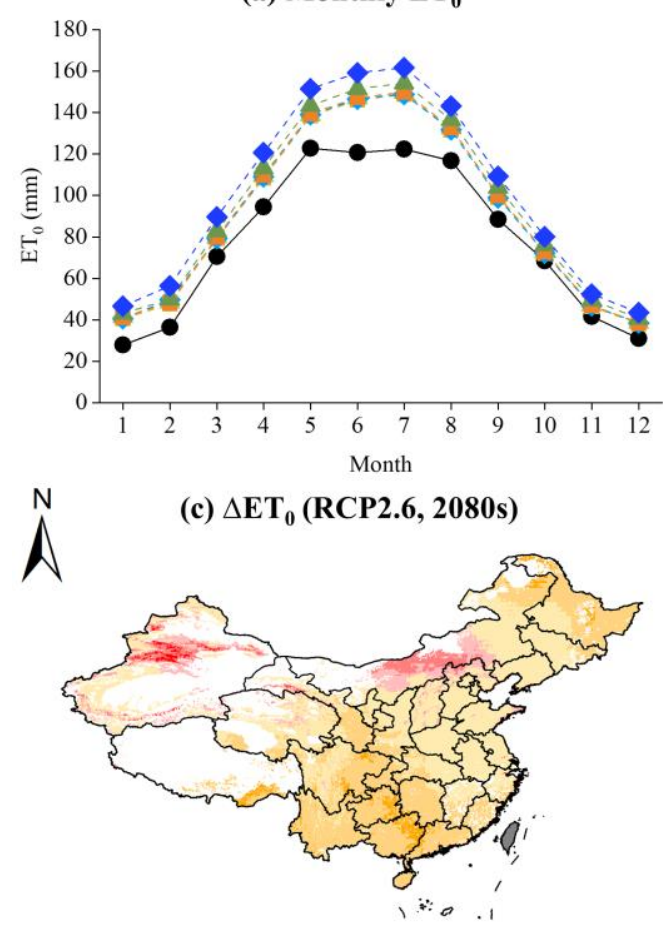

(e) $\triangle \mathrm{ET}_{0}(\mathrm{RCP8.5}, 2080 \mathrm{~s})$

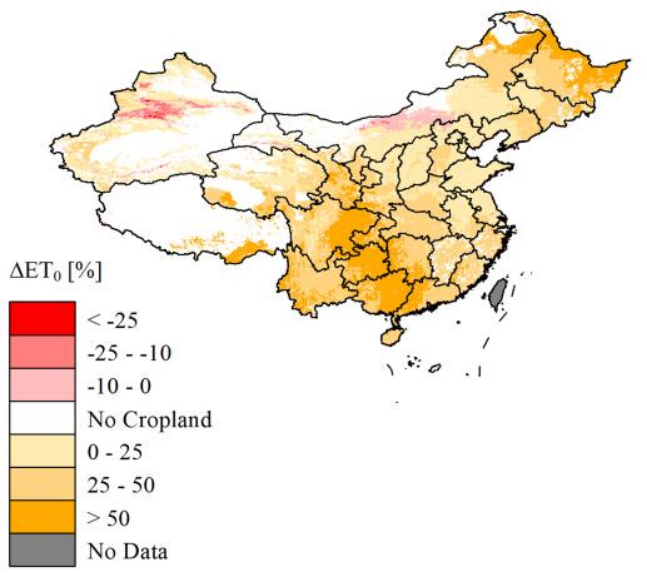

(b) Monthly PR

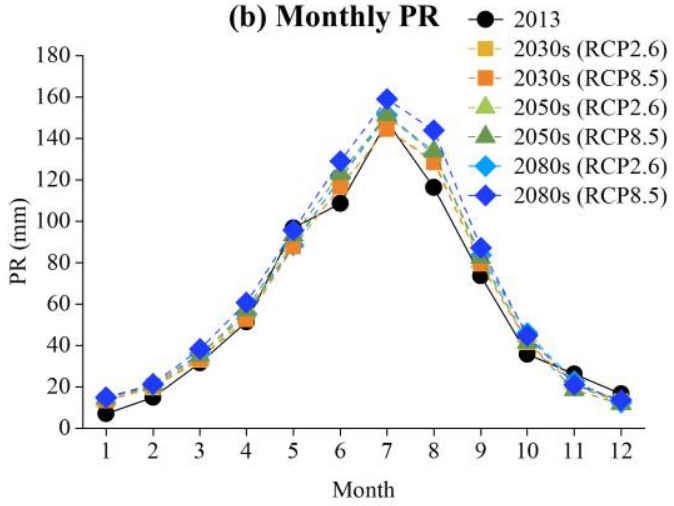

(d) $\triangle \mathrm{PR}(\mathrm{RCP2.6}, 2080 \mathrm{~s})$

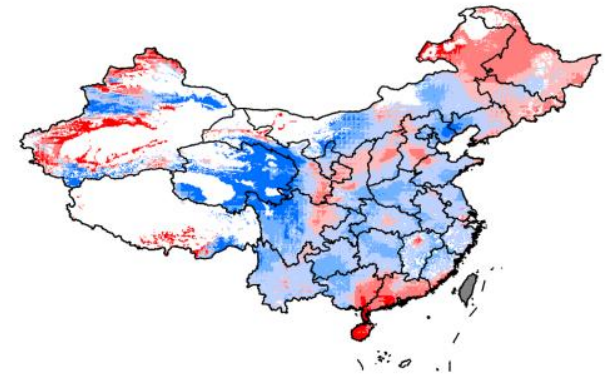

(f) $\triangle \mathrm{PR}(\mathrm{RCP8.5}, 2080 \mathrm{~s})$

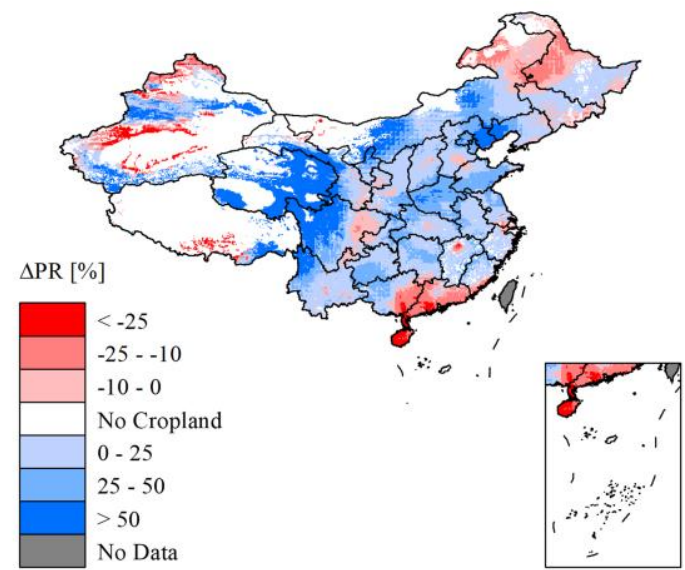

Figure 2. Future climate projections for the maize and wheat planted zones in China.

\subsection{WFP distribution in the baseline year 2013}

The national average WFP for wheat $\left(1,008 \mathrm{~m}^{3} \mathrm{t}^{-1}\right)$ was higher than that for maize $\left(813 \mathrm{~m}^{3} \mathrm{t}^{-1}\right)$ in the baseline year 2013.

180 The corresponding blue water footprint proportions were $37 \%$ and $20 \%$, respectively. The reason for this discrepancy is that maize is a $\mathrm{C} 4$ crop while wheat is a $\mathrm{C} 3$ crop. $\mathrm{C} 4$ crops have a relatively higher $\mathrm{CO}_{2}$ fixation efficiency and faster photosynthetic 
rate than $\mathrm{C} 3$ crops. Hence, maize can accumulate comparatively more yield than wheat under the same water consumption

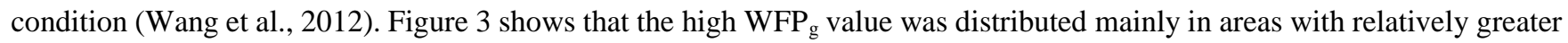
precipitation during crop growth, i.e., abundant green water resources. The main component of WFP is WFP. Therefore, the high maize WFP was distributed mainly in Northwest (Fig. 3a) while the high wheat WFP was distributed mainly in Southwest and South Coast (Fig. 3b). Elevated $\mathrm{ET}_{0}$ and insufficient precipitation can increase blue water consumption in food production. Thus, the high $\mathrm{WFP}_{\mathrm{b}}$ value was distributed mainly in areas with uneven water and heat resource distributions during crop growth. The high maize $\mathrm{WFP}_{\mathrm{b}}$ was distributed mainly in Northwest and East Coast (Fig. 3c) while that of wheat was distributed mainly in North China (Fig. 3d). In all grids, the proportions of $\mathrm{WFP}_{\mathrm{b}}$ and $\mathrm{WFP}_{\mathrm{g}}$ were up to $68 \%$ (wheat in Xinjiang) (Table S2) and $98 \%$ (maize in Hainan) (Table S1), respectively.

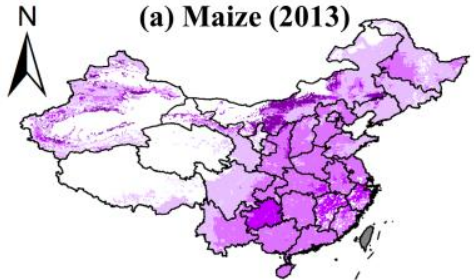

(c) Maize (2013)
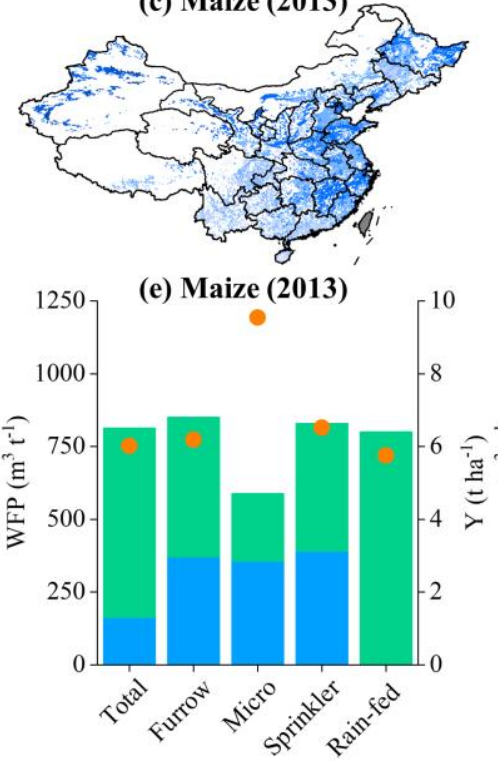

(b) Wheat (2013)

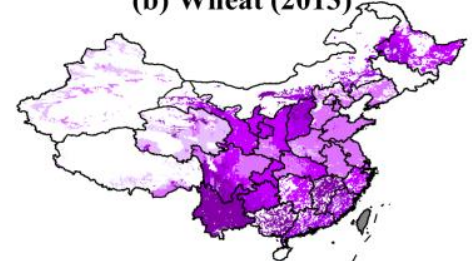

(d) Wheat (2013)

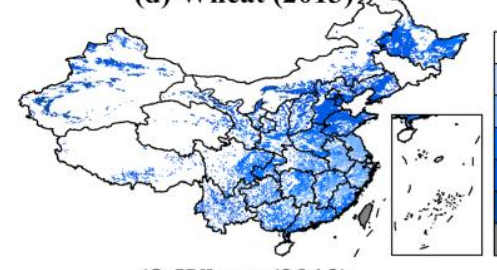

(f) Wheat (2013) $\quad[10$

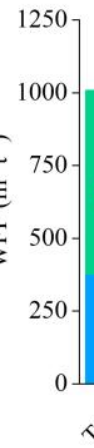

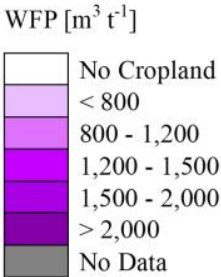

The ratio of $\mathrm{WFP}_{\mathrm{b}}$ to WFP [\%]

No Cropland

$<10$

$10-30$

$30-50$

$50-70$

$>70$

No Data

Figure 3. WFP of maize and wheat in China in 2013.

A comparison of rain-fed and irrigation techniques disclosed that the WFP of maize and wheat under furrow and sprinkler irrigation was higher than that under rain-fed in 2013. The WFP of micro-irrigated crops was lower than that of rain-fed crops. The WFP of maize $\left(850 \mathrm{~m}^{3} \mathrm{t}^{-1}\right)$ and wheat $\left(1,170 \mathrm{~m}^{3} \mathrm{t}^{-1}\right)$ was highest under furrow and sprinkler irrigation, respectively. For wheat under all three irrigation techniques, $\mathrm{WFP}_{\mathrm{b}}$ was dominant $(54-65 \%)$. However, $\mathrm{WFP}_{\mathrm{b}}$ for maize was only dominant 
under micro irrigation (61\%). Micro-irrigated (9.55 $\mathrm{t} \mathrm{ha}^{-1}$ for maize and $5.46 \mathrm{t} \mathrm{ha}^{-1}$ for wheat) and rain-fed $\left(5.76 \mathrm{t}\right.$ ha ${ }^{-1}$ for maize and $4.51 \mathrm{t} \mathrm{ha}^{-1}$ for wheat) crops had the highest and lowest yield, respectively, in 2013. The responses of maize yield to rain-fed and various irrigation techniques were stronger than those of wheat yield (Fig. 3e, f).

\subsection{Spatiotemporal responses of WFP to future climate change}

Compared with the baseline year 2013 and at the national average level, maize WFP will increase under both RCP2.6 and RCP8.5, by $17 \%$ and $13 \%$, respectively, until the 2080s. The WFP of wheat will increase under RCP2.6 (by $12 \%$ until the 2080s), but decrease by $12 \%$ under RCP8.5 until the 2080s (Fig. 4a). The increases in $\mathrm{CO}_{2}$ concentration and, by extension, yield gain, will be lower under RCP2.6 than RCP8.5. During the same period, the increases in WFP under RCP2.6 will be 1$3 \%$ higher for maize and 2-10\% higher for wheat than those under RCP8.5. There will be relatively smaller differences in $\mathrm{CO}_{2}$ concentration between climate scenarios of the 2030s (431 ppm under RCP2.6 and 449 ppm under RCP8.5). Thus, the differences in WFP between RCPs will be smaller before the 2030s and larger after the 2050s. The WFP of irrigated wheat under RCP 8.5 will decline in the second half of this century, by $3 \%$ until the 2050s, and by $15 \%$ until the 2080s. The increase in WFP will be highest under rain-fed. The WFP of rain-fed maize and wheat under RCP2.6 will increase by $19 \%$ and $24 \%$, respectively, until the 2080s. By contrast, the WFP of irrigated maize and wheat under RCP2.6 will only increase by $13 \%$ and $7 \%$, respectively, until the 2080s (Fig. 4a). A comparison of the various irrigation techniques demonstrated that the WFPs of wheat and maize respond differently under the same scenario. The increase in WFP amplitude for maize will be highest under furrow irrigation (14\% and $11 \%$ under RCP2.6 and RCP8.5 until the 2080s, respectively) and lowest under micro irrigation (5\% and $2 \%$ under RCP2.6 and RCP8.5 until the 2080s, respectively). The WFP of sprinkler-irrigated wheat under RCP8.5 will decline by $1 \%$ until the 2030s. The WFP of wheat under micro irrigation has the highest increase (9\% until the 2080s under RCP2.6) and the lowest decrease (14\% until the 2080s under RCP8.5). The WFP of wheat under sprinkler irrigation has the lowest increase (only $2 \%$ until the 2080s under RCP2.6) and the highest decrease (19\% until the 2080s under RCP8.5) 220 (Fig. 4b). 

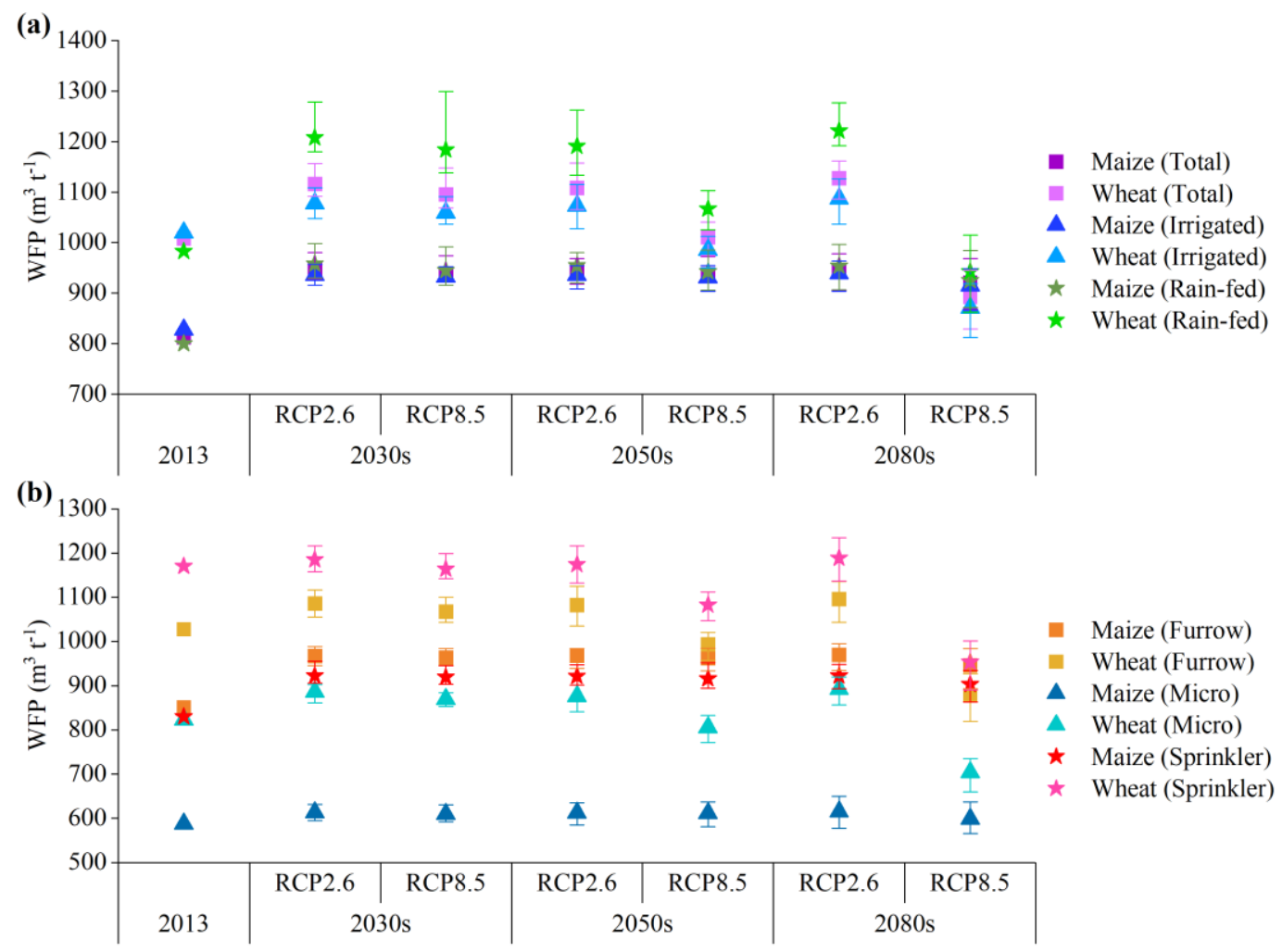

Figure 4. WFP of maize and wheat in 2013 and future year levels under various climate change scenarios in China.

The spatial distribution of the relative changes in maize and wheat WFP from 2013 to the 2080s shows regional differences. The WFP will increase for 90-93\% of all areas planted with maize (Fig. 5a, b). The WFP will increase for $78 \%$ of all areas planted with wheat under RCP2.6 (Fig. 5c) and decrease for $81 \%$ of all areas planted with wheat under RCP8.5 (Fig. 5d). Increases in $\mathrm{ET}_{0}$ lead to increases in WFP while decreases in PR lead to increases in $\mathrm{WFP}_{\mathrm{b}}$ (Fig. S6). Hence, the regions with relatively greater increases in WFP are distributed mainly where $\mathrm{ET}_{0}$ strongly increases and PR slightly increases or even decreases. In Yunnan, maize WFP increases by $44 \%$ and $38 \%$ under RCP2.6 and RCP8.5, respectively. In Guangxi, wheat WFP increases by $50 \%$ and $16 \%$ under RCP2.6 and RCP8.5, respectively (Table S5). Comparison of rainfed and various irrigation techniques reveals that WFP of each crop responds uniquely to latitudinal and longitudinal climate change under the same scenario. The responses of maize WFP to climate change with latitude are relatively consistent. It increases by $27-43 \%$ at $19-26^{\circ} \mathrm{N}$ and $\sim 51^{\circ} \mathrm{N}$ latitude and decreases at $\sim 44{ }^{\circ} \mathrm{N}$ latitude. By contrast, the responses of WFP for rain-fed maize are more sensitive at $\sim 40{ }^{\circ} \mathrm{N}$ and $\sim 52{ }^{\circ} \mathrm{N}$ latitude. The responses of maize WFP vary widely within $74-$ $100{ }^{\circ} \mathrm{E}$ longitude. The WFP of maize under rain-fed and furrow and sprinkler irrigation decline at $74-90{ }^{\circ} \mathrm{E}$ longitude. The increase in WFP for maize under rain-fed at $93-98^{\circ} \mathrm{E}$ longitude is 3-51\% higher than the increase in WFP for maize under furrow and sprinkler irrigation. The WFP of micro-irrigated maize decreases at $74-95^{\circ} \mathrm{E}$ longitude (Fig. 5a, b). The responses 
https://doi.org/10.5194/hess-2021-568

Preprint. Discussion started: 1 December 2021

(c) Author(s) 2021. CC BY 4.0 License.

of wheat WFP to climate change with latitude and longitude are relatively consistent. In certain areas, however, there are large differences in wheat WFP between rain-fed and the three irrigation techniques. The WFP of wheat under rain-fed declines at $74-80{ }^{\circ} \mathrm{E}$ longitude and to a greater extent than the WFP of wheat under the three irrigation techniques at the same longitude range. The increases in the WFP of wheat under rain-fed at $\sim 93^{\circ} \mathrm{E}$ and $\sim 122^{\circ} \mathrm{E}$ longitude and $\sim 22^{\circ} \mathrm{N}$ latitude are significantly higher than the increases in WFP of wheat under the three irrigation techniques (Fig. 5c, d).

(a) Maize (RCP2.6, 2080s)

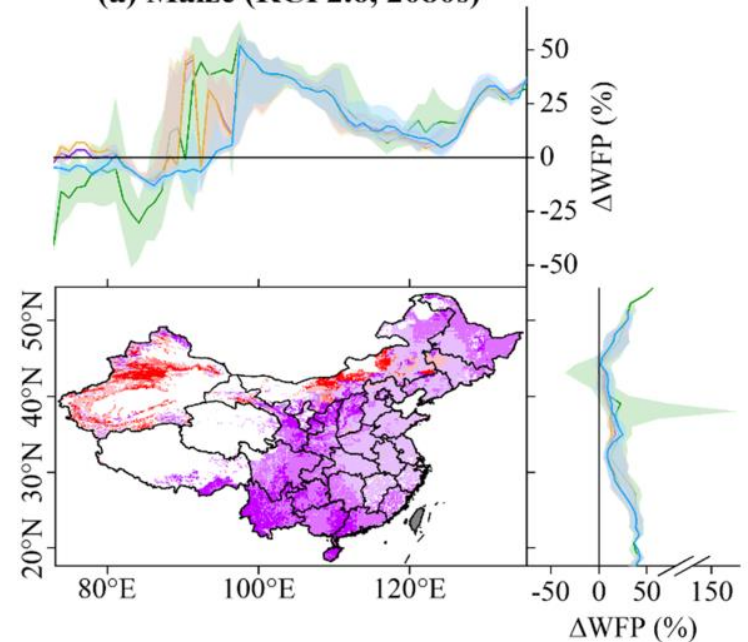

(c) Wheat (RCP2.6, 2080s)

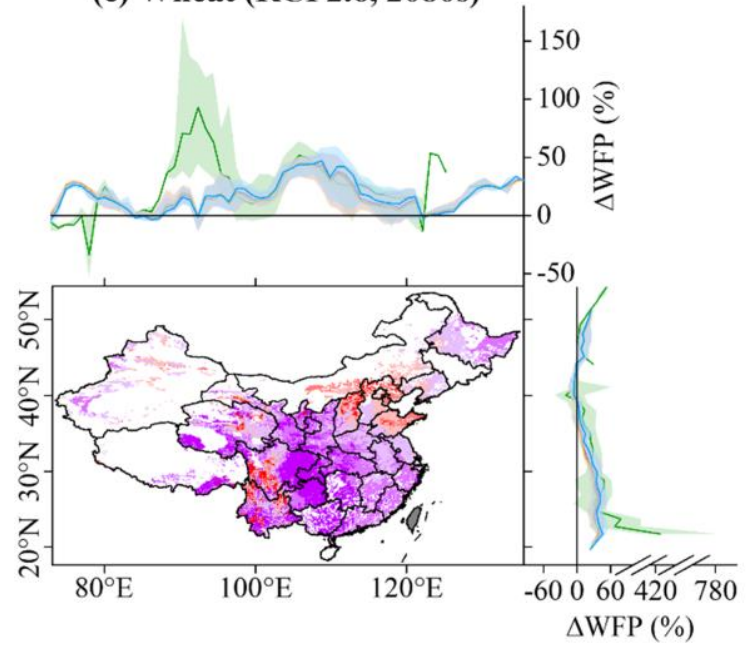

(b) Maize (RCP8.5, 2080s)

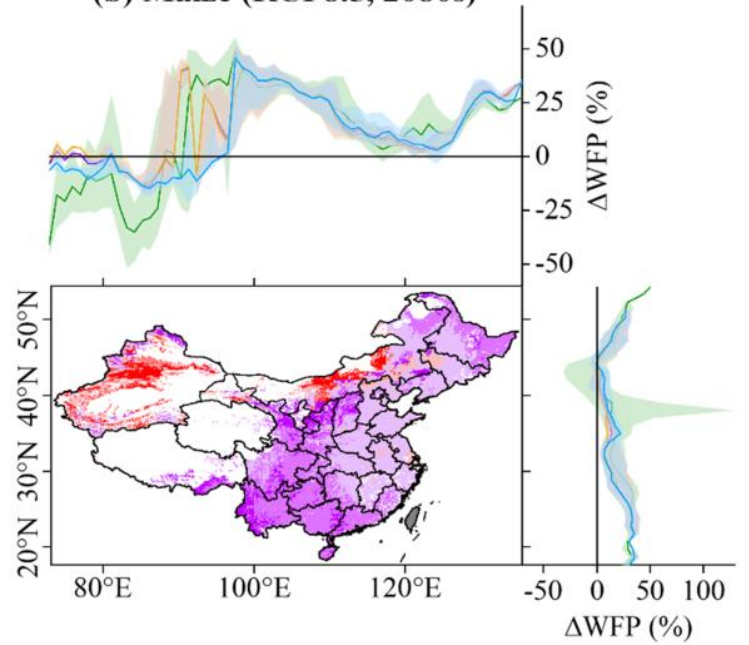

(d) Wheat (RCP8.5, 2080s)

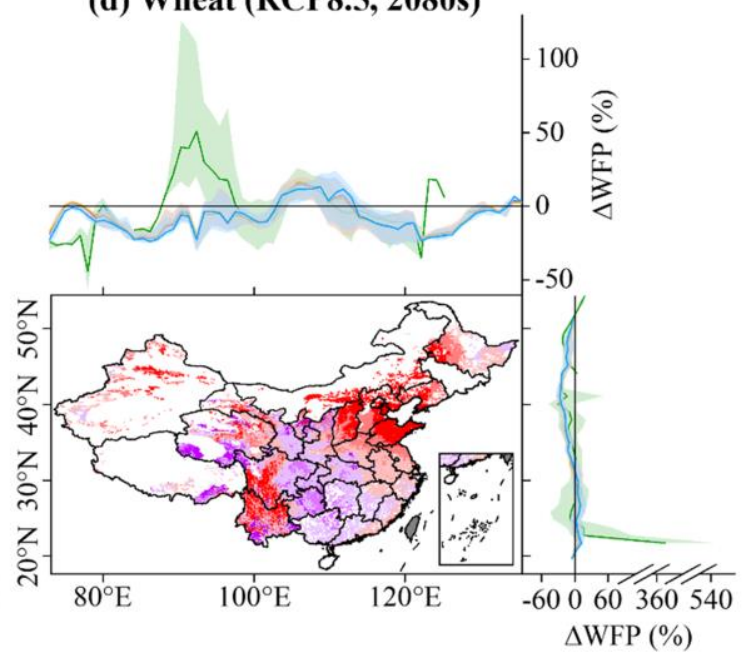

$\triangle \mathrm{WFP}[\%]$

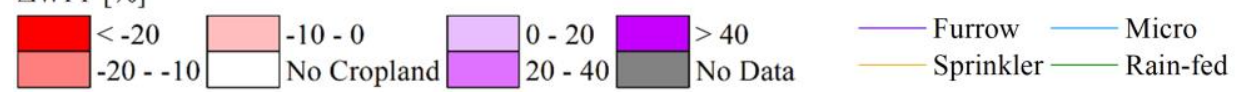

Figure 5. Spatial distributions in relative changes $\Delta(\%)$ in WFP (bottom left panel) with longitudinal (top panel) and latitudinal (right panel) changes under different irrigation techniques applied to both crops under two scenarios from 2013 to the 2080 s. 
WFP is determined both by crop yield (Y) and crop water use (CWU). We compared the relationships between the relative changes in WFP $(\triangle \mathrm{WFP})$ and corresponding $\mathrm{Y}(\Delta \mathrm{Y})$ and CWU $(\triangle \mathrm{CWU})$ (Fig. 6). $\Delta$ WFP of maize and wheat under future climate change scenarios is inversely proportional to $\Delta \mathrm{Y}$ and directly proportional to $\Delta \mathrm{CWU}$. Nevertheless, $\Delta \mathrm{WFP}$ is relatively more sensitive to $\Delta \mathrm{Y}$. When $\Delta \mathrm{Y}$ is $25 \%, \Delta \mathrm{WFP}$ of wheat under RCP2.6 and maize is approximately $-25 \%$ while $\Delta \mathrm{WFP}$ of wheat under RCP8.5 is approximately $-10 \%$. When $\triangle \mathrm{CWU}$ is $25 \%, \Delta \mathrm{WFP}$ of wheat under RCP2.6 and maize is $20 \%$ while $\Delta \mathrm{WFP}$ of wheat under RCP8.5 is approximately $-8 \%$ (Fig. 6a, b). The responses of $\Delta \mathrm{WFP}$ of maize are more sensitive to $\Delta \mathrm{Y}$ and $\triangle \mathrm{CWU}$ than those of wheat. The responses of $\triangle \mathrm{WFP}$ of maize and wheat under RCP2.6 are more sensitive to $\Delta \mathrm{Y}$ and $\triangle \mathrm{CWU}$ than those under RCP8.5. Comparison of rain-fed and various irrigation techniques revealed that the correlation between $\Delta \mathrm{WFP}$ and $\Delta \mathrm{Y}$ is stronger for rain-fed crops. For rain-fed maize, $\mathrm{R}^{2}$ can reach 0.55 (Fig. 6a). $\Delta \mathrm{WFP}$ and $\Delta \mathrm{CWU}$ are strongly correlated for irrigated crops. In fact, $\triangle \mathrm{WFP}$ and $\Delta \mathrm{CWU}$ are especially strongly correlated for crops under micro irrigation ( $\mathrm{R}^{2}$ can reach 0.98 for wheat) (Fig. 6b). We also compared the relationship between $\Delta \mathrm{WFP}_{\mathrm{b}}$ and $\Delta \mathrm{CWU} \mathrm{U}_{\mathrm{b}}$, and found that it resembled that between $\triangle \mathrm{WFP}$ and $\Delta \mathrm{CWU}$ but more significant (Fig. 6c). 
https://doi.org/10.5194/hess-2021-568

Preprint. Discussion started: 1 December 2021

(c) Author(s) 2021. CC BY 4.0 License.

(c) (1)
Hydrology and

Earth System

Sciences

Discussions

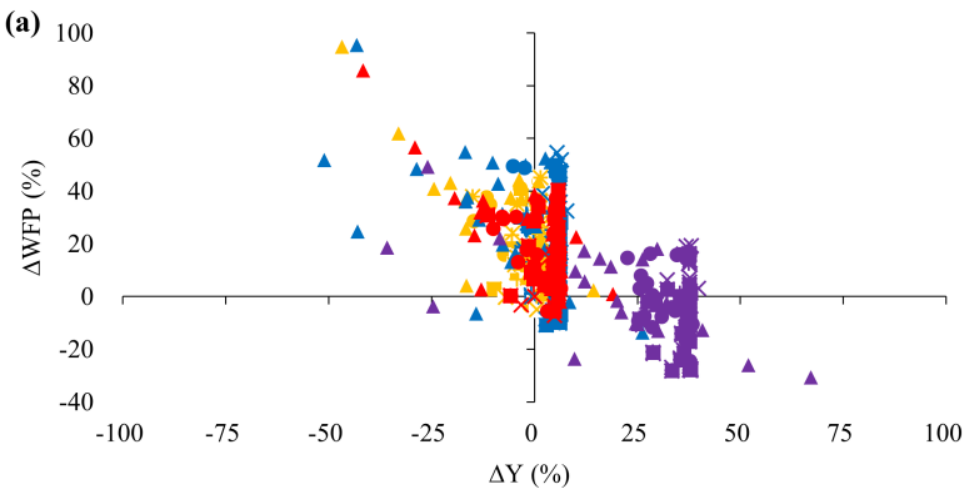

(b) 100

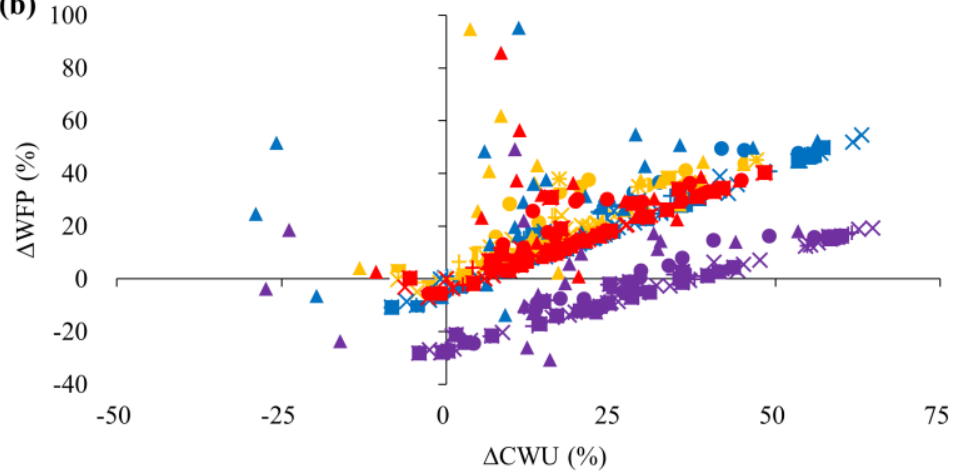

(c) 250

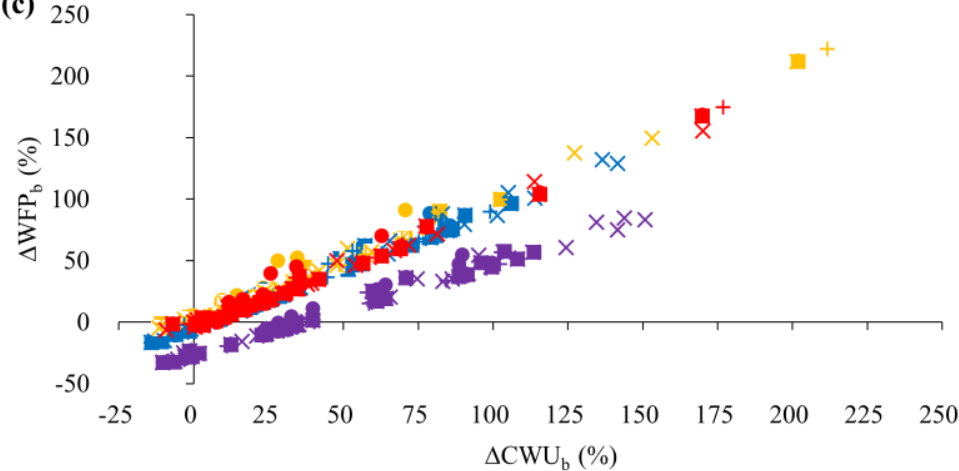

- Maize (RCP2.6, Total)

- Wheat (RCP2.6, Total)

$=$ Maize (RCP2.6, Irrigated)

च Wheat (RCP2.6, Irrigated)

* Maize (RCP2.6, Furrow)

* Wheat (RCP2.6, Furrow)

$\times$ Maize (RCP2.6, Micro)

$\times$ Wheat (RCP2.6, Micro)

+ Maize (RCP2.6, Sprinkler)

+ Wheat (RCP2.6, Sprinkler)

$\triangle$ Maize (RCP2.6, Rain-fed)

$\triangle$ Wheat (RCP2.6, Rain-fed)

- Maize (RCP8.5, Total)

- Wheat (RCP8.5, Total)

- Maize (RCP8.5, Irrigated)

Wheat (RCP8.5, Irrigated)

* Maize (RCP8.5, Furrow)

* Wheat (RCP8.5, Furrow)

$\times$ Maize (RCP8.5, Micro)

$\times$ Wheat (RCP8.5, Micro)

+ Maize (RCP8.5, Sprinkler)

+ Wheat (RCP8.5, Sprinkler)

$\triangle$ Maize (RCP8.5, Rain-fed)

$\Delta$ Wheat (RCP8.5, Rain-fed)

Figure 6. Relationships between relative changes $\Delta$ (\%) in (a) Y and corresponding WFP, (b) CWU and corresponding WFP, and (c) $\mathrm{CWU}_{\mathrm{b}}$ and corresponding $\mathrm{WFP}_{\mathrm{b}}$ of two crops under RCP2.6 and RCP8.5 from 2013 to the 2080s.

\section{3.4 Spatiotemporal WFP benchmarks responses to climate change}

Table 2 shows WFP benchmarks of maize and wheat among various irrigation techniques and climate zones in 2013 and future year levels. WFP benchmarks of maize and wheat in the humid zone are 13-32\% higher than those in the arid zone, which is similar to Wang et al. (2019). In the same climate zone, WFP benchmarks of wheat are generally 2-35\% higher than those of maize. In the humid zone, however, the WFP benchmark for the 25th production percentile of maize will be $3 \%$ 
https://doi.org/10.5194/hess-2021-568

Preprint. Discussion started: 1 December 2021

(C) Author(s) 2021. CC BY 4.0 License.
Hydrology and

Earth System Sciences

Discussions

270 higher than that of wheat under RCP8.5 in the 2080s. In the arid zone, WFP benchmarks of rain-fed maize are 13-34\% higher than those of irrigated maize. In the humid zone of the future, WFP benchmarks of rain-fed wheat will be $2-7 \%$ higher than those of irrigated wheat. In general, WFP benchmarks of sprinkler-irrigated crops are higher while those of micro-irrigated crops are lower. The differences in WFP benchmarks among various irrigation techniques are more significant in the arid zone. WFP benchmarks of the crops under micro irrigation are 30-38\% lower than those under sprinkler irrigation in the arid zone.

275 The difference in the humid zone is only $8-14 \%$. This is also consistent with Wang et al. (2019). In the humid zone, however, WFP benchmarks of maize under furrow irrigation are $7-21 \%$ higher than those under sprinkler irrigation.

Table 2. WFP benchmarks $\left(\mathrm{m}^{3} \mathrm{t}^{-1}\right)$ of maize and wheat for different climate zones in 2013 and future year levels under two climate change scenarios in China.

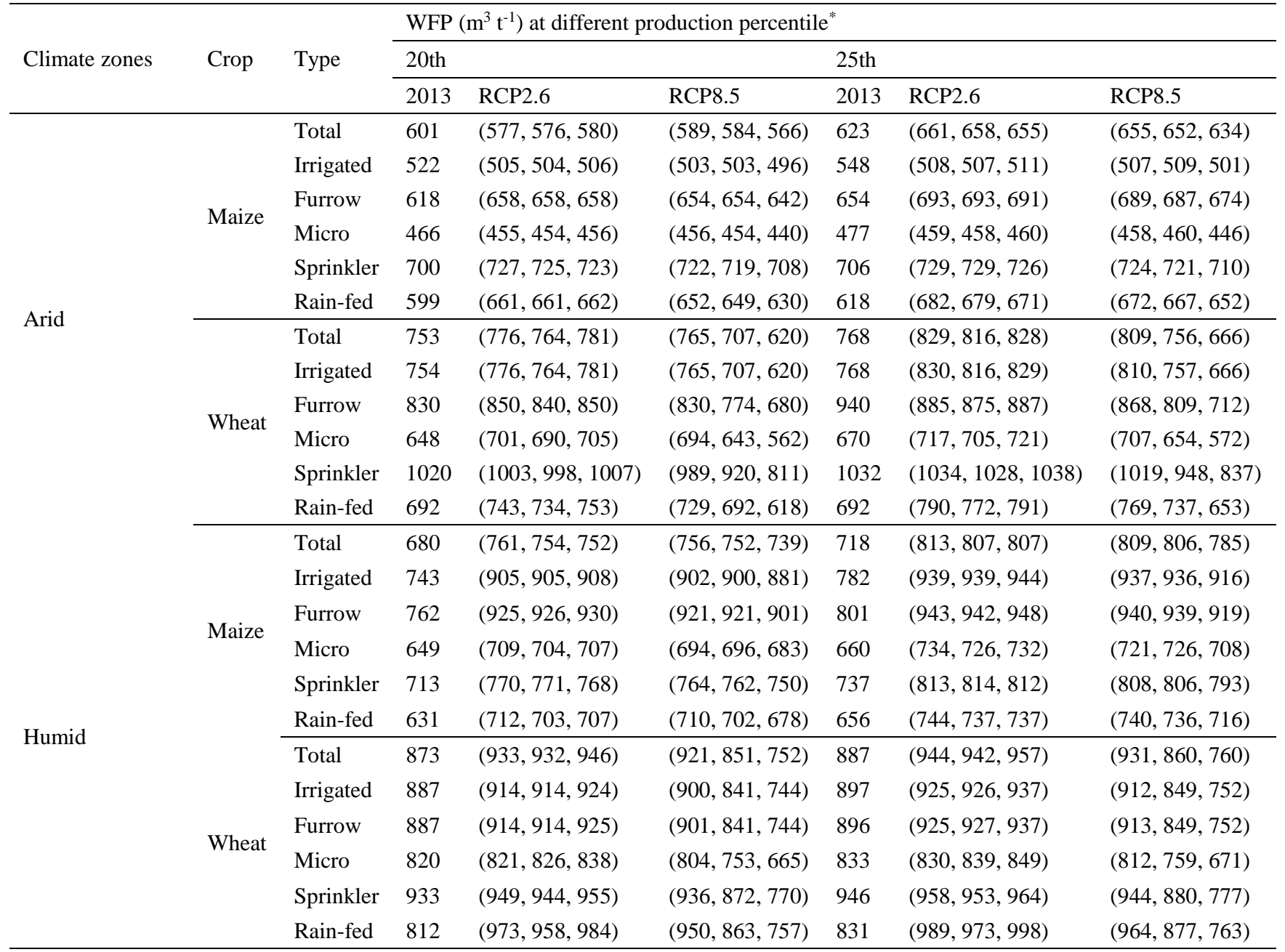

*The three numbers in brackets are the values of 2030s, 2050s and 2080s. 
Compared with the baseline year 2013, the changes in maize and wheat WFP benchmarks under future climate change scenarios are similar to the changes in WFP. However, the WFP benchmark for the 20th production percentile of maize will decline by $2-6 \%$ in the arid zone. WFP benchmarks of wheat under RCP8.5 will decrease by $2-6 \%$ and $13-18 \%$ until the 2050s and the 2080s, respectively. The increasing range of the WFP benchmark for the 25th production percentile of maize is $7-8 \%$ higher in the humid zone than that in the arid zone. The increasing range of the WFP benchmark for the 20th production percentile of wheat is $4-5 \%$ higher in the humid zone than that in the arid zone. WFP benchmarks of maize and wheat increase to a greater extent under RCP2.6 but decrease to a greater extent under RCP8.5. WFP benchmarks of rain-fed crops increase more than those of irrigated crops in the same climate zone. Nevertheless, the increase in WFP benchmarks is 7-11\% lower for rain-fed than irrigated maize in the humid zone. WFP benchmarks of maize and wheat generally increase relatively more under furrow irrigation and comparatively less under sprinkler irrigation. However, under RCP2.6, the growth rate of the WFP benchmark for the 20th production percentile of wheat is 5-6\% higher under micro irrigation than that under furrow irrigation in the arid zone. The increase in the WFP benchmark for the 20th production percentile of wheat is $0.19-2 \%$ higher under sprinkler irrigation than that under micro irrigation in the humid zone (Table 2).

Figure 7 shows the spatial distribution of the relative changes in WFP of maize and wheat compared with the benchmark for the 25th production percentile in 2013 and the 2080s. In 2013, the WFP for $81 \%$ and $79 \%$ of the maize and wheat planted areas, respectively, was higher than its benchmark. The maize planted areas with WFP below the benchmark were distributed mainly in Xinjiang in the arid zone and northeast Inner Mongolia in the humid zone (Fig. 7a). The wheat planted areas with WFP below the benchmark were distributed mainly in Xinjiang in the arid zone and Qinghai (Fig. 7d). Under future climate change scenarios, the maize and wheat planted areas with WFP below the benchmark will slightly decrease in the 2080s. These areas are mainly distributed in Heilongjiang, Tibet, southern Gansu and Sichuan in the humid zone for maize, and Henan, Tibet in the humid zone and Qinghai for wheat. This is because that the annual $\mathrm{ET}_{0}$ will increase relatively faster in Heilongjiang and Tibet which will, in turn, lead to a greater increase in $\mathrm{WFP}_{\mathrm{b}}$. The annual PR in other regions will significantly increase which will result in a greater increase in $\mathrm{WFP}_{\mathrm{g}}$. Maize and wheat planted areas under RCP8.5 with WFP below the benchmark will decrease by $5 \%$ and $4 \%$, respectively, until the 2080 s. 


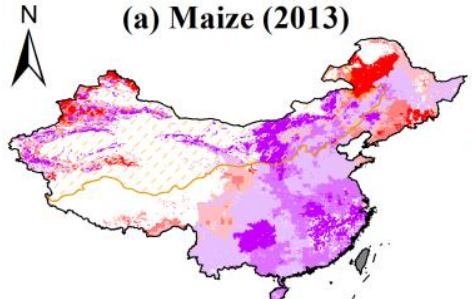

(d) Wheat (2013)

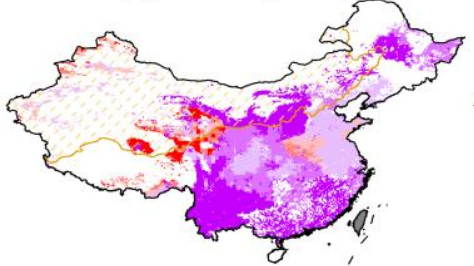

$\Delta$ WFP compared with the benchmark for the 25 th production percentile [\%]

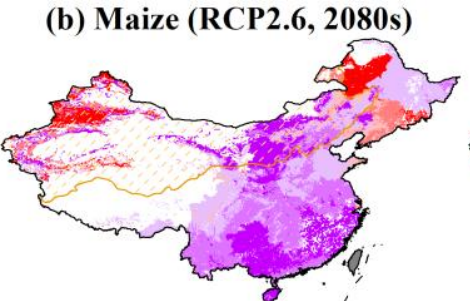

(e) Wheat (RCP2.6, 2080s)
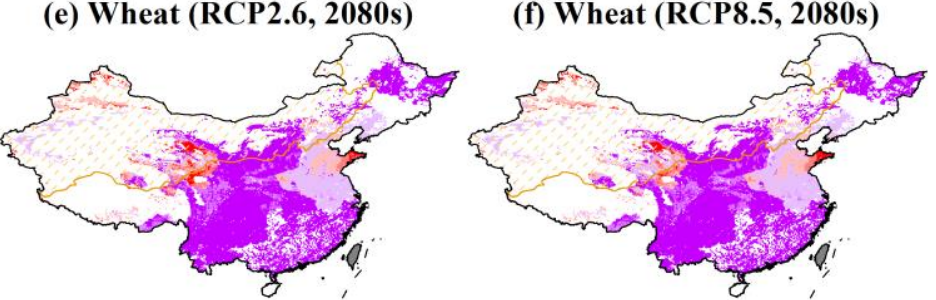

(c) Maize (RCP8.5, 2080s)

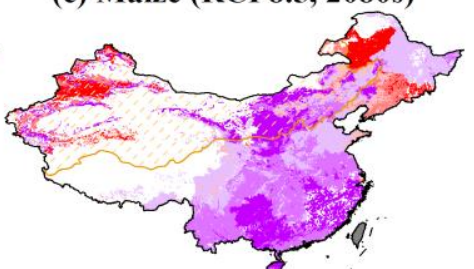

(f) Wheat (RCP8.5, 2080s)
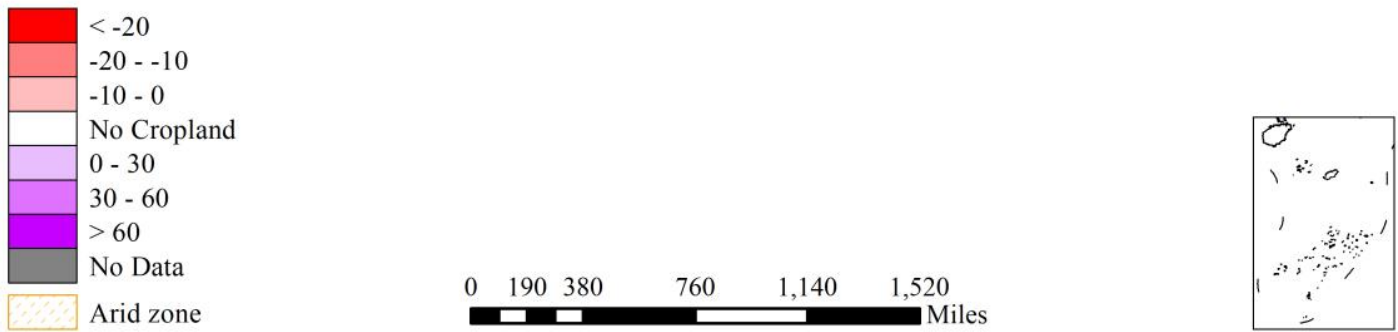

Figure 7. Relative changes $\Delta(\%)$ in WFP of maize and wheat compared with the benchmark for the 25 th production percentile in 2013 and the 2080s under RCP2.6 and RCP8.5 in different climate zones of China.

\subsection{Discussion}

This study analysed and compared the WFP and WFP benchmarks responses of wheat and maize under rain-fed and various irrigation conditions and forecasted their responses to future climate change scenarios in China. Under the background that the annual $\mathrm{ET}_{0}$ and PR will both increase but $\mathrm{ET}_{0}$ will increase faster, maize WFP will increase under both two RCPs. Wheat WFP will increase under RCP2.6 but decrease under RCP8.5 until the 2080s. Rain-fed crops have higher ranges of increasing WFP, which is consistent with Rosa et al. (2020). The increasing ranges of maize and wheat WFP are lowest under micro irrigation and sprinkler irrigation, respectively. Therefore, the implementation of water-saving irrigation techniques (micro and sprinkler irrigation) might help mitigate the adverse effects of future climate change on agriculture, which is in line with Dai et al. (2020). Under future climate change, WFP benchmarks will be modified in a manner resembling that for WFP. However, the former changes will not be as significant as the latter in spatial distribution. 
In 2013, WFP of maize was lower than that of wheat. Nevertheless, maize WFP is expected to increase more rapidly than wheat WFP under future climate change scenarios. C4 crops such as maize have higher photosynthetic rates than C3 crops such as wheat. However, the former are less sensitive to elevated atmospheric $\mathrm{CO}_{2}$ than the latter (Bowes, 1993). Hence, while maize yield is higher than wheat yield, the former increases less than the latter. We compared current results against those of previous studies in Table 3. The differences we determined for the relative changes in maize and wheat WFP between years and RCPs resembled those reported by Zhuo et al. (2016c). However, these authors also considered other factors such as harvested crop area, technology, diet, and population that could partially offset the adverse effects of future climate change. Therefore, maize and wheat WFP will decline in the future according to Zhuo et al. (2016c). Fader et al. (2010) studied relative global-scale changes in maize WFP for the year 2050. Their analysis was conducted in the opposite direction of that of the present study on China. Moreover, the two studies differed in terms of climate scenario, research area, and crop model. Winter wheat WFP in Germany and Italy will decline by 2050 according to Garofalo et al. (2019). Nevertheless, our research showed that winter wheat WFP will increase in China by 2050. The crop water use in Germany and Italy changes more slightly than that in China. However, our observed differences in the relative changes in WFP between RCPs were consistent with those of Garofalo et al. (2019), namely, under RCP8.5, WFP will either decrease more or increase less.

Table 3. Comparison of the results between current and previous studies.

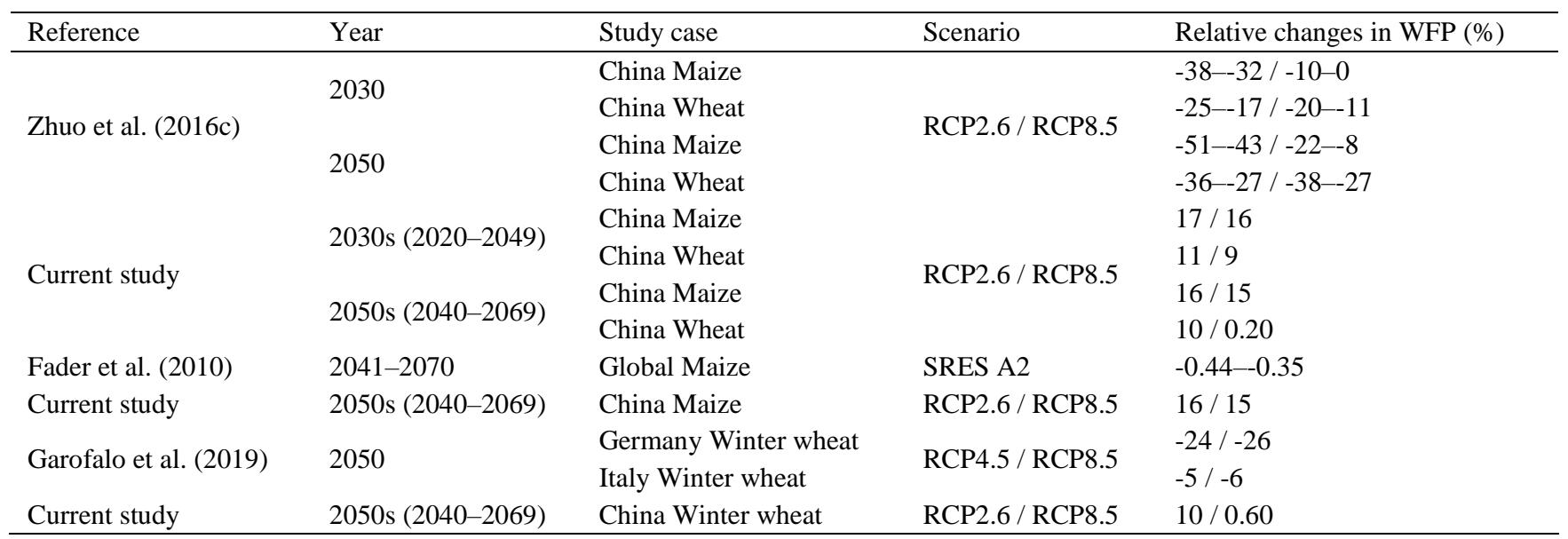

In the future, the spatial distributions of maize and wheat WFP will change considerably. By contrast, the spatial distributions of WFP benchmarks will change relatively little. This phenomenon is comparatively more pronounced in areas with limited agricultural development. In 2013, Guizhou and Guangxi had the highest maize and wheat WFP $\left(1,317 \mathrm{~m}^{3} \mathrm{t}^{-1}\right.$ and $3,720 \mathrm{~m}^{3} \mathrm{t}^{-1}$, respectively) (Table $\mathrm{S} 1, \mathrm{~S} 2$ ). In the humid zone, maize WFP in Guizhou and wheat WFP in Guangxi will increase by $37 \%$ and $50 \%$, respectively, under RCP2.6 and by $33 \%$ and 16\%, respectively, under RCP8.5 until the 2080s (Table S5). Nevertheless, the WFP benchmarks for the 25th production percentile of maize and wheat in the humid zone will only increase 345 by $12 \%$ and $8 \%$, respectively, under RCP2.6 and increase by $9 \%$ and decrease by $14 \%$, respectively, under RCP 8.5 . These 
areas will nonetheless have great potential for agricultural water conservation in the future. If maize and wheat WFP in various regions of China can be reduced to the benchmark for the 25 th production percentile, the total CWU can be reduced by $45-66$ billion $\mathrm{m}^{3}(\sim 14-17 \%)$. Rain-fed agriculture can save $27-40$ billion $\mathrm{m}^{3}(\sim 18-22 \%)$ water which is more than that conserved by irrigation. In irrigated agriculture, furrow irrigation has a comparatively high water-saving potential (17-22 billion $\mathrm{m}^{3}$; 11-12\%). To optimise the agricultural water-saving potential in China, we must either reduce WFP or prevent it from increasing either by enhancing crop yield or decreasing CWU. However, this goal can only be realised with the support of relevant policies and management practices. The annual PR is relatively low and the $\mathrm{ET}_{0}$ is relatively high in North China. Shortage of water for agriculture is a major bottleneck in the development of local agriculture there. However, furrow irrigation is mainly applied in these areas (Fig. S3). Hence, irrigation water use efficiency is low and $\mathrm{WFP}_{\mathrm{b}}$ is high. High-efficiency, water-saving micro irrigation and sprinkler irrigation could replace furrow irrigation there so that CWU and WFP are decreased. The planted areas in the South have abundant precipitation but limited distribution (Fig. S2) and high WFP (Fig. 3a, b). WFP can be mitigated by implementing ground cover techniques (ex. straw return, mulch) to reduce soil evaporation and by improving farmer skills. WFP can also be reduced by optimizing crops planting structure. Crops and varieties best adapted to local climate conditions and climate change can lower irrigation requirements and reduce WFP.

In order to make climate models comparable and promote the development of them, The World Climate Research Program (WCRP) has developed and promoted the CMIP since 1995 (Meehl et al., 1997, 2000). Its current iteration is CMIP Phase 6 (CMIP6) which will be used in the forthcoming Intergovernmental Panel on Climate Change's Sixth Assessment Report (IPCC AR6). GCMs and their associated research results based on CMIP5 provided vital support for IPCC's Fifth Assessment Report (IPCC AR5). CMIP5 proposed four RCP scenarios (RCP2.6, RCP4.5, RCP6.0, and RCP8.5) by considering greenhouse gas (GHG) emissions and concentrations, atmospheric pollutant concentrations, and land use in the $21^{\text {st }}$ century (Moss et al., 2008). However, no specific socio-economic assumptions were made. The Scenario Model Intercomparison Project (ScenarioMIP) as the primary activity within CMIP6 will provide a series of new climate scenarios that consider social factors related to climate change adaptation and impacts. They will be based on the combined application of shared socioeconomic pathways (SSPs) and RCPs and will compensate for the shortcomings of the RCPs in CMIP5 (O’Neill et al., 2016). The climate models in CMIP5 and CMIP6 can both effectively simulate changes in potential evapotranspiration (Liu et al., 2020) and precipitation (Müller et al., 2021) in most parts of the world. Müller et al. (2021) reported that CMIP5 and CMIP6 simulate increasing trends in temperature in a similar fashion. Nevertheless, the simulation generated by CMIP6 is higher than that by CMIP5. Notwithstanding, CMIP5 and CMIP6 are reasonably consistent and similar in terms of their abilities to predict future climate changes. This study focused on the responses of crop production to future climate change. It considered mainly the influences of GHG emission- and concentration-driven climate change and excluded the influences of alterations in socioeconomic development. For these reasons, we implemented CMIP5 in our research here.

The sources of uncertainty in research on the responses of crop production to climate change include GCMs, climate scenarios, crop models, and their interactions (Wang et al., 2020). Semenov and Stratonovitch (2010) proposed that the use of multiple GCMs can reduce the uncertainty associated with them. We selected three GCMs each for wet and dry climate outputs 
to encompass a broad climate prediction scenario. To project the future climate change trends of China objectively and comprehensively, we selected two extreme RCPs, namely, RCP2.6 and RCP8.5. Wang et al. (2020) suggested that crop models are the main source of uncertainty in predicting wheat yield in China under future climate change. The application of various crop models and parameter settings inevitably lead to different yield forecasts (Asseng et al., 2013). Hence, the use of AquaCrop alone may introduce uncertainty into WFP forecasting.

The present study had certain limitations in terms of the assumptions it made for the simulation. First, we assumed that the crop parameters (such as planting calendar, HI, Zx, and so on) for each crop under the identical planting mode (irrigated or rain-fed) were constant on a spatiotemporal scale. Yoon and Choi (2020) proposed that future increases in temperature and precipitation might shorten the crop growth period. Xiao et al. (2020) indicated that the winter wheat and summer maize growing periods will be lengthened and shortened, respectively, under future climate change. However, we did not consider future changes in the crop growth period. Second, we assumed a constant soil surface moisture rate for each grid under the various irrigation techniques. Third, it was assumed that the observed changes in the planted areas in 2013 were based on the 2000 raster database and ignored planted areas migration. Finally, we assumed that the maize and wheat planted areas will not change in the future and would remain consistent with baseline year 2013. Thus, we did not consider future development of cultivated lands.

The core content of this study was to quantify the responses of maize and wheat WFP and WFP benchmarks to future climate change under various irrigation techniques. To this end, we coupled the AquaCrop model to the GCMs outputs. Future research must improve the accuracy of the crop model simulation and reduce the uncertainty of climate prediction associated with using different GCMs. Moreover, this study only considered future climate change scenarios. Future investigations should also consider the influence of changes in technological development, land use, planting modes, and so on.

\section{Conclusions}

This study explored the responses of maize and wheat WFP accounting and benchmarking to future climate change in China. The crops were subjected to various irrigation techniques. The year 2013 was the baseline and WFP and its benchmarks were quantified for each crop under rain-fed and irrigation (furrow, micro, and sprinkler) managements in the 2030s, 2050s, and 2080s under RCP2.6 and RCP8.5 at a 5-arc grid scale. AquaCrop model coupled with six GCMs in CMIP5 was used. The results show that: (1) Compared with 2013, the annual $\mathrm{ET}_{0}$ and PR in the maize and wheat planted areas of China will both increase but the former will increase faster than the latter. (2) Maize WFP will increase under both RCP2.6 and RCP8.5, by $17 \%$ and $13 \%$, respectively, until the 2080s. Wheat WFP will increase under RCP2.6 (by $12 \%$ until the 2080s), but decrease by $12 \%$ under RCP8.5 until the 2080s. Rain-fed crops are more vulnerable to the adverse impacts of future climate change and their WFP increases to a greater extent than that of irrigated crops. Micro irrigation and sprinkler irrigation result in the

410 lowest increases in WFP for maize and wheat, respectively. Hence, these water-saving irrigation practices effectively mitigate the negative impact of climate change. (3) Within different climate zones and under various irrigation techniques, there will 
be significant differences in the responses of WFP benchmarks to future climate change. The changes in WFP and its benchmarks will be similar in response to future climate change. The rate of increase in WFP benchmarks for sprinklerirrigated crops will generally be lower than those for rain-fed, micro-irrigated, and furrow-irrigated crops within the same climate zone. However, the change in the spatial distribution of WFP benchmarks will not be as significant as that of WFP itself. Moreover, the differences in the spatial distributions of WFP and its benchmarks will be more pronounced in regions with low agricultural development. Additionally, this study demonstrated that agricultural water can be effectively conserved in China. To this end, management practices should include water-saving irrigation, ground cover such as mulching and straw return, improvement of farmer skills, optimizing crops planting structure. In this manner, the agricultural water-saving potential of China can be maximised and sustainable water supply and food production security can be established and maintained under future climate change.

Data availability. Data sources are listed in Sect. 2.4. Data generated in this paper are available by contacting La Zhuo.

Competing interests. The authors declare that they have no conflict of interest.

\section{Acknowledgements}

The study is financially supported by the Program for Cultivating Outstanding Talents on Agriculture, Ministry of Agriculture and Rural Affairs, People's Republic of China [13210321], and the National Natural Science Foundation of China Grants [51809215].

\section{References}

Ahmadi, M., Etedali, H. R., and Elbeltagi, A.: Evaluation of the effect of climate change on maize water footprint under RCPs scenarios in Qazvin plain, Iran, Agr. Water Manage., 254, 106969, https://doi.org/10.1016/j.agwat.2021.106969, 2021.

Allen, R. G., Pereira, L. S., Raes, D., and Smith, M.: Crop evapotranspiration-Guidelines for computing crop water requirements-FAO Irrigation and drainage paper 56, 300, FAO, Rome, Italy, 1998.

Arora, V. K., Scinocca, J. F., Boer, G. J., Christian, J. R., Denman, K. L., Flato, G. M., Kharin, V. V., Lee, W. G., and Merryfield, W. J.: Carbon emission limits required to satisfy future representative concentration pathways of greenhouse gases, Geophys. Res. Lett., 38, 387-404, https://doi.org/10.1029/2010GL046270, 2011.

Arunrat, N., Pumijumnong, N., Sereenonchai, S., Chareonwong, U., and Wang, C.: Assessment of climate change impact on rice yield and water footprint of large-scale and individual farming in Thailand, Sci. Total Environ., 726, 137864, https://doi.org/10.1016/j.scitotenv.2020.137864, 2020. 
Asseng, S., Ewert, F., Rosenzweig, C., Jones, J. W., Hatfield, J. L., Ruane, A. C., Boote, K. J., Thorburn, P. J., Rötter, R. P., Cammarano, D., Brisson, N., Basso, B., Martre, P., Aggarwal, P. K., Angulo, C., Bertuzzi, P., Biernath, C., Challinor, A. J., Doltra, J., Gayler, S., Goldberg, R., Grant, R., Heng, L., Hooker, J., Hunt, L. A., Ingwersen, J., Izaurralde, R. C., Kersebaum, K. C., Müller, C., Naresh Kumar, C., Nendel, C., O’Leary, G., Olesen, J. E., Osborne, T. M., Palosuo, T., Priesack, E., Ripoche, D., Semenov, M. A., Shcherbak, I., Steduto, P., Stöckle, C., Stratonovitch, P., Streck, T., Supit, I., Tao, F., Travasso, M., Waha, K., Wallach, D., White, J. W., Williams, J. R., and Wolf, J.: Uncertainty in simulating wheat yields under climate change, Nat. Clim. Chang., 3, 827-832, https://doi.org/10.1038/nclimate1916, 2013.

Batjes, N.: ISRIC-WISE Derived Soil Properties on a 5 by 5 Arc-Minutes Global Grid (Ver. 1.2), ISRIC, Wageningen, The Netherlands, available at: https://www.isric.org, 2012.

Bowes, G.: Facing the Inevitable: Plants and Increasing Atmospheric CO2, Annu. Rev. Plant Phys. Plant Mol. Biol., 44, 309332, https://doi.org/10.1146/annurev.pp.44.060193.001521, 1993.

CCAFS: CCAFS-Climate Statistically Downscaled Delta Method data, Climate Change, Agriculture and Food Security, available at: www.ccafs-climate.org, 2015.

CEDA: Climatic Research Unit (CRU) time-series datasets of variations in climate with variations in other phenomena, NCAS British Atmospheric Data Centre, date of citation, available at: http://catalogue.ceda.ac.uk/uuid, 2018.

Chukalla, A. D., Krol, M. S., and Hoekstra, A. Y.: Green and blue water footprint reduction in irrigated agriculture: Effect of irrigation techniques irrigation strategies and mulching, Hydrol. Earth Syst. Sci., 19, 4877-4891, https://doi.org/10.5194/hess-19-4877-2015, 2015.

Dai, C., Qin, X. S., Lu, W. T., and Huang, Y.: Assessing adaptation measures on agricultural water productivity under climate change: A case study of Huai River Basin, China, Sci. Total Environ., 721, 137777, https://doi.org/10.1016/j.scitotenv.2020.137777, 2020.

Delworth, T. L., Broccoli, A. J., Rosati, A., Stouffer, R. J., Balaji, V., Beesley, J. A., Cooke, W. F., Dixon, K. W., Dunne, J., Dunne, K. A., Durachta, J. W., Findell, K. L., Ginoux, P., Gnanadesikan, A., Gordon, C. T., Griffies, S. M., Gudgel, R., Harrison, M. J., Held, I. M., Hemler, R. S., Horowitz, L. W., Klein, S. A., Knutson, T. R., Kushner, P. J., Langenhorst, A. R., Lee, H. C., Lin, S. J., Lu, J., Malyshev, S. L., Milly, P. C. D., Ramaswamy, V., Russell, J., Schwarzkopf, M. D., Shevliakova, E., Sirutis, J. J., Spelman, M. J., Stern, W. F., Winton, M., Wittenberg, A. T., Wyman, B., Zeng, F., and Zhang, R.: GFDL's CM2 Global Coupled Climate Models. Part I: Formulation and Simulation Characteristics, J. Clim., 19, 643-674, https://doi.org/10.1175/JCLI3629.1, 2006.

Dijkshoorn, J. A., Engelen, V. W. P. V., and Huting, J. R. M.: Soil and landform properties for LADA partner countries (Argentina, China, Cuba, Senegal, South Africa and Tunisia), ISRIC-World Soil Information and FAO, Wageningen, the Netherlands, available at: https://www.isric.org/, https://doi.org/10.13031/2013.42676, 2008.

Donner, L. J., Wyman, B. L., Hemler, R. S., Horowitz, L. W., Ming, Y., Zhao, M., Golaz, J. C., Ginoux, P., Lin, S. J., Schwarzkopf, M. D., Austin, J., Alaka, G., Cooke, W. F., Delworth, T. L., Freidenreich, S. M., Gordon, C. T., Griffies, S. M., Held, I. M., Hurlin, W. J., Klein, S. A., Knutson, T. R., Langenhorst, A. R., Lee, H. C., Lin, Y., Magi, B. I., 
Malyshev, S. L., Milly, P. C. D., Naik, V., Nath, M. J., Pincus, R., Ploshay, J. J., Ramaswamy, V., Seman, C. J., Shevliakova, E., Sirutis, J. J., Stern, W. F., Stouffer, R. J., Wilson, R. J., Winton, M., Wittenberg, A. T., and Zeng, F.: The Dynamical Core, Physical Parameterizations, and Basic Simulation Characteristics of the Atmospheric Component AM3 of the GFDL Global Coupled Model CM3, J. Clim., 24, 3484-3519, https://doi.org/10.1175/2011JCLI3955.1, 2011. Dufresne, J. L., Foujols, M. A., Denvil, S., Caubel, A., Marti, O., Aumont, O., Balkanski, Y., Bekki, S., Bellenger, H., Benshila, R., Bony, S., Bopp, L., Braconnot, P., Brockmann, P., Cadule, P., Cheruy, F., Codron, F., Cozic, A., Cugnet, D., Noblet, N. D., Duvel, J. P., Ethé, C., Fairhead, L., Fichefet, T., Flavoni, S., Friedlingstein, P., Grandpeix, J. Y., Guez, L., Guilyardi, E., Hauglustaine, D., Hourdin, F., Idelkadi, A., Ghattas, J., Joussaume, S., Kageyama, M., Krinner, G., Labetoulle, S., Lahellec, A., Lefebvre, M. P., Lefevre, F., Levy, C., Li, Z. X., Lloyd, J., Lott, F., Madec, G., Mancip, M., Marchand, M., Masson, S., Meurdesoif, Y., Mignot, J., Musat, I., Parouty, S., Polcher, J., Rio, C., Schulz, M., Swingedouw, D., Szopa, S., Talandier, C., Terray, P., Viovy, N., and Vuichard, N.: Climate change projections using the IPSL-CM5 Earth System Model: from CMIP3 to CMIP5, Clim. Dyn., 40, 2123-2165, https://doi.org/10.1007/s00382-012-1636-1, 2013.

Fader, M., Rost, S., Müller, C., Bondeau, A., and Gerten, D.: Virtual water content of temperate cereals and maize: Present and potential future patterns, J. Hydrol., 384, 218-231, https://doi.org/10.1016/j.jhydrol.2009.12.011, 2010.

FAO: FAOSTAT on-line database, Food and Agriculture Organization of the United Nation, Rome, Italy, available at: http://www.fao.org/faostat/en/\#data/QC, 2021.

Garofalo, P., Ventrella, D., Kersebaum, K. C., Gobin, A., Trnka, M., Giglio, L., Dubrovský, M., and Castellini, M.: Water footprint of winter wheat under climate change: Trends and uncertainties associated to the ensemble of crop models, Sci. Total Environ., 658, 1186-1208, https://doi.org/10.1016/j.scitotenv.2018.12.279, 2019.

Harris, I., Jones, P. D., Osborn, T. J., and Lister, D. H: Updated high-resolution grids of monthly climatic observations - the CRU TS3.10 Dataset, Int. J. Climatol., 34, 623-642, https://doi.org/10.1002/joc.3711, 2014.

Hatfield, J. L. and Dold, C.: Water-Use Efficiency: Advances and Challenges in a Changing Climate, Front. Plant Sci., 10, 103, https://doi.org/10.3389/fpls.2019.00103, 2019.

Hoekstra, A. Y. (ed.): Virtual water trade: Proceedings of the International Expert Meeting on Virtual Water Trade, Delft, the Netherlands, 12-13 December 2002, Value of Water Research Report Series No. 12, UNESCO-IHE, Delft, The Netherlands, 2003.

Hoekstra, A. Y.: The water footprint of modern consumer society, Routledge, London, UK, 208 pp, 2013.

Hoekstra, A. Y.: Sustainable, efficient, and equitable water use: the three pillars under wise freshwater allocation, Wiley Interdiscip. Rev. Water, 1, 31-40, https://doi.org/10.1002/wat2.1000, 2013.

Hoekstra, A. Y., Chapagain, A. K., Aldaya, M. M., and Mekonnen, M. M.: The Water Footprint Assessment Manual: Setting the Global Standard, Earthscan, London, UK, 2011.

Hurrell, J. W., Holland, M. M., Gent, P. R., Ghan, S., Kay, J. E., Kushner, P. J., Lamarque, J. F., Large, W. G., Lawrence, D., Lindsay, K., Lipscomb, W. H., Long, M. C., Mahowald, M., Marsh, D. R., Neale, R. B., Rasch, P., Vavrus, S., Vertenstein, M., Bader, D., Collins, W. D., Hack, J. J., Kiehl, J., and Marshall, S.: The Community Earth System Model: A Framework 
for Collaborative Research, Bull. Am. Meteorol. Soc., 94, 1339-1360, https://doi.org/10.1175/BAMS-D-12-00121.1, 2013.

IPCC: Summary for Policymakers. In: Climate Change 2021: The Physical Science Basis. Contribution of Working Group I to the Sixth Assessment Report of the Intergovernmental Panel on Climate Change, edited by: Masson-Delmotte, V., Zhai, P., Pirani, A., Connors, S. L., Péan, C., Berger, S., Caud, N., Chen, Y., Goldfarb, L., Gomis, M. L., Huang, M., Leitzell, K., Lonnoy, E., Matthews, J. B. R., Maycock, T. K., Waterfield, T., Yelekçi, O., Yu, R., and Zhou, B., Cambridge University Press, In Press, 2021.

Jans, Y., Bloh, W. V., Schaphoff, S., and Müller, C.: Global cotton production under climate change - Implications for yield and water consumption, Hydrol. Earth Syst. Sci., 25, 2027-2044, https://doi.org/10.5194/hess-25-2027-2021, 2021.

Kappelle, M.: WMO Statement on the State of the Global Climate in 2019, World Meteorological Organization, Geneva, Switzerland, 2020.

Konapala, G., Mishra, A. K., Wada, Y., and Mann, M. E.: Climate change will affect global water availability through compounding changes in seasonal precipitation and evaporation, Nat. Commun., 11, 3044, https://doi.org/10.1038/s41467-020-16757-w, 2020.

Liu, X., Li, C., Zhao, T., and Han, L.: Future changes of global potential evapotranspiration simulated from CMIP5 to CMIP6 models, Atmos. Oceanic Sci Lett., 13, 568-575, https://doi.org/10.1080/16742834.2020.1824983, 2020.

Lobell, D. B. and Gourdji, S. M.: The influence of climate change on global crop productivity, Plant Physiol., 160, 1686-1697, https://doi.org/10.1104/pp.112.208298, 2012.

Mali, S. S., Shirsath, P. B., and Islam, A.: A high-resolution assessment of climate change impact on water footprints of cereal production in India, Sci. Rep., 11, 8715, https://doi.org/10.1038/s41598-021-88223-6, 2021.

Meehl, G. A., Boer, G. J., Covey, C., Latif, M., and Stouffer, R. J.: Intercomparison makes for a better climate model, Eos. Trans. Amer. Geophys. Union, 78, 445-451, https://doi.org/10.1029/97EO00276, 1997.

Meehl, G. A., Boer, G. J., Covey, C., Latif, M., and Stouffer, R. J.: The Coupled Model Intercomparison Project (CMIP), Bull. Am. Meteorol. Soc., 81, 313-318, https://doi.org/10.1175/1520-0477(2000)081<0313:TCMIPC>2.3.CO;2, 2000.

Mekonnen, M. M. and Hoekstra, A. Y.: The green, blue and grey water footprint of crops and derived crop products, Hydrol. Earth Syst. Sci., 15, 1577-1600, doi:10.5194/hess-15-1577-2011, 2011.

Mekonnen, M. M. and Hoekstra, A. Y.: Water footprint benchmarks for crop production: A first global assessment, Ecol. Indic., 46, 214-223, https://doi.org/10.1016/j.ecolind.2014.06.013, 2014.

Mialyk, O., Schyns, J. F., Booij, M. J., and Hogeboom, R. J.: Historical simulation of maize water footprints with a new global gridded crop model ACEA, Hydrol. Earth Syst. Sci. Discuss. [preprint], https://doi.org/10.5194/hess-2021-329, in review, 2021.

540 Middleton, N. and Thomas, D. S. G.: World atlas of desertification, Arnold, London, UK, 1997.

Moss, R., Babiker, M., Brinkman, S., Calvo, E., Carter, T., Edmonds, J., Elgizouli, I., Emori, S., Erda, L., Hibbard, K., Jones, R., Kainuma, M., Kelleher, J., Lamarque, J. F., Manning, M., Matthews, B., Meehl, J., Meyer, L., Mitchell, J., 
Nakicenovic, N., O’Neill, B., Pichs, R., Riahi, K., Rose, S., Runci, P., Stouffer, R., van Vuuren, D., Weyant, J., Wilbanks, T., van Ypersele, J. P., and Zurek, M.: Towards New Scenarios for Analysis of Emissions, Climate Change, Impacts, and Response Strategies, IPCC Expert Meeting Report, 19-21 September, 2007, Noordwijkerhout, Netherlands, Intergovernmental Panel on Climate Change (IPCC), Geneva, Switzerland, 132 pp, 2008.

Müller, C., Franke, J., Jägermeyr, J., Ruane, A. C., Elliott, J., Moyer, E., Heinke, J., Falloon, P. D., Folberth, C., Francois, L., Hank, T., César Izaurralde, R., Jacquemin, I., Liu, W., Olin, S., Pugh, T. A. M., Williams, K., and Zabel, F.: Exploring uncertainties in global crop yield projections in a large ensemble of crop models and CMIP5 and CMIP6 climate scenarios, Environ. Res. Lett., 16, 034040, https://doi.org/10.1088/1748-9326/abd8fc, 2021.

Myers, S. S., Smith, M. R., Guth, S., Golden, C. D., Vaitla, B., Mueller, N. D., Dangour, A. D., and Huybers, P.: Climate Change and Global Food Systems: Potential Impacts on Food Security and Undernutrition, Annu. Rev. Public Health, 38, 259-277, https://doi.org/10.1146/annurev-publhealth-031816-044356, 2017.

Navarro-Racines, C., Tarapues, J., Thornton, P., Jarvis, A., and Ramirez-Villegas, J.: High-resolution and bias-corrected CMIP5 projections for climate change impact assessments, Sci. Data, 7, 7, https://doi.org/10.1038/s41597-019-0343-8, 2020.

NBSC: National Data, China, National Bureau of Statistics, Beijing, China, available at: https://data.stats.gov.cn/, 2021.

NOAA: National Oceanic and Atmospheric Administration, U.S, available at: https://www.esrl.noaa.gov, 2018.

O’Neill, B. C., Tebaldi, C., van Vuuren, D. P., Eyring, V., Friedlingstein, P., Hurtt, G., Hurtt, R., Kriegler, E., Lamarque, J. F., Lowe, J., Meehl, G. A., Moss, R., Riahi, K., and Sanderson, B. M.: The Scenario Model Intercomparison Project (ScenarioMIP) for CMIP6, Geosci. Model Dev., 9, 3461-3482, https://doi.org/10.5194/gmd-9-3461-2016, 2016.

Pastor, A. V., Palazzo, A., Havlik, P., Biemans, H., Wada, Y., Obersteiner, M., Kabat, P., and Ludwig, F.: The global nexus of food-trade-water sustaining environmental flows by 2050, Nat. Sustain., 2, 499-507, https://doi.org/10.1038/s41893019-0287-1, 2019.

Portmann, F. T., Siebert, S., and Döll, P.: MIRCA2000-Global monthly irrigated and rainfed crop areas around the year 2000: A new high-resolution data set for agricultural and hydrological modelling, Global Biogeochem. Cy., 24, https://doi.org/10.1029/2008gb003435, 2010.

Qiao, F., Song, Z., Bao, Y., Song, Y., Shu, Q., Huang, C., and Zhao, W.: Development and evaluation of an Earth System Model with surface gravity waves, J. Geophys. Res. Ocean., 118, 4514-4524, https://doi.org/10.1002/jgrc.20327, 2013.

Raes, D., Steduto, P., Hsiao, T. C., and Fereres, E.: Reference manual, Chapter 2, AquaCrop model, Version 6.0, Food and Agriculture Organization of the United Nations, Rome, Italy, 2017.

Rallison, R. E.: Origin and evolution of the SCS runoff equation, in: Symposium on Watershed Management, Boise, Idaho, United States, 21-23 July, 912-924, 1980.

Riahi, K., Gruebler, A., and Nakicenovic, N.: Scenarios of long-term socio-economic and environmental development under climate stabilization, Technol. Forecast. Soc. Chang., 74, 887-935, https://doi.org/10.1016/j.techfore.2006.05.026, 2007. 
Rosa, L., Chiarelli, D. D., Sangiorgio, M., Beltran-Peña, A. A., Rulli, M. C., D’Odorico, P., and Fung, I.: Potential for sustainable irrigation expansion in a $3^{\circ} \mathrm{C}$ warmer climate, Proc. Natl. Acad. Sci. U. S. A., 117, 29526-29534, https://doi.org/10.1073/pnas.2017796117, 2020.

Schmidt, G. A., Kelley, M., Nazarenko, L., Ruedy, R., Russell, G. L., Aleinov, I., Bauer, M., Bauer, S. E., Bhat, M. K., Bleck, R., Canuto, V., Chen, Y. H., Cheng, Y., Clune, T. L., Genio, A. D., Fainchtein, R. D., Faluvegi, G., Hansen, J. E., Healy, R. J., Kiang, N. Y., Koch, D., Lacis, A. A., LeGrande, A. N., Lerner, J., Lo, K. K., Matthews, E. E., Menon, S., Miller, R. L., Oinas, V., Oloso, A. O., Perlwitz, J. P., Puma, M. J., Putman, W. M., Rind, D., Romanou, A., Sato, M., Shindell, D. T., Sun, S., Syed, R. A., Tausnev, N., Tsigaridis, K., Unger, N., Voulgarakis, A., Yao, M. S., and Zhang, J.: Configuration and assessment of the GISS ModelE2 contributions to the CMIP5 archive, J. Adv. Model. Earth Syst., 6, 141-184, https://doi.org/10.1002/2013MS000265, 2014.

Schmidt, G. A., Ruedy, R., Hansen, J. E., Aleinov, I., Bell, N., Bauer, M., Bauer, S., Cairns, B., Canuto, V., Cheng, Y., Delgenio, A. D., Faluvegi, G., Friend, A. D., Hall, T. M., Hu, Y., Kelley, M., Kiang, N. Y., Koch, D., Lacis, A. A., Lerner, J., Lo, K. K., Miller, R. L., Nazarenko, L., Oinas, V., Perlwitz, J., Perlwitz, J., Rind, D., Romanou, A., Russell, G. L., Sato, M., Shindell, D. T., Stone, P. H., Sun, S., Tausnev, N., Thresher, D., and Yao, M. S.: Present-Day Atmospheric Simulations Using GISS ModelE: Comparison to In Situ, Satellite, and Reanalysis Data, J. Clim., 19, 153-192, https://doi.org/10.1175/JCLI3612.1, 2006.

Semenov, M. A. and Stratonovitch, P.: Use of multi-model ensembles from global climate models for assessment of climate change impacts, Clim. Res., 41, 1-14, https://doi.org/10.3354/cr00836, 2010.

Tian, Y., Ruth, M., Zhu, D., Ding, J., and Morris, N.: A Sustainability Assessment of Five Major Food Crops' Water Footprints in China from 1978 to 2010, Sustainability, 11, 1-20, https://doi.org/10.3390/su11216179, 2019.

Trnka, M., Feng, S., Semenov, M. A., Olesen, J. E., Kersebaum, K. C., Rötter, R. P., Semerádová, D., Klem, K., Huang, W., Ruiz-Ramos, M., Hlavinka, P., Meitner, J., Balek, J., Havlík, P., and Büntgen, U.: Mitigation efforts will not fully alleviate the increase in water scarcity occurrence probability in wheat-producing areas, Sci. Adv., 5, eaau2406, https://doi.org/10.1126/sciadv.aau2406, 2019.

USDA: Estimation of direct runoff from storm rainfall, Section 4 Hydrology, Chapter 4, National Engineering Handbook, Washington DC, USA, 1-24, 1964.

van Vuuren, D. P., den Elzen, M. G. J., Lucas, P. L., Eickhout, B., Strengers, B. J., van Ruijven, B., Wonink, S., and van Houdt, R.: Stabilizing greenhouse gas concentrations at low levels: an assessment of reduction strategies and costs, Clim. Change, 81, 119-159, https://doi.org/10.1007/s10584-006-9172-9, 2007.

von Salzen, K., Scinocca, J. F., McFarlane, N. A., Li, J., Cole, J. N. S., Plummer, D., Verseghy, D., Reader, M. C., Ma, X., Lazare, M., and Solheim, L.: The Canadian Fourth Generation Atmospheric Global Climate Model (CanAM4). Part I: Representation of Physical Processes, Atmosphere-Ocean, 51, 104-125, https://doi.org/10.1080/07055900.2012.755610, 2013. 
Wang, B., Feng, P., Liu, D. L., O’Leary, G. J., Macadam, I., Waters, C., Asseng, S., Cowie, A., Jiang, T., Xiao, D., Ruan, H., $\mathrm{He}$, J., and Yu, Q.: Sources of uncertainty for wheat yield projections under future climate are site-specific, Nat. Food., 1, 720-728, https://doi.org/10.1038/s43016-020-00181-w, 2020.

Wang, C., Guo, L., Li, Y., and Wang, Z.: Systematic Comparison of C3 and C4 Plants Based on Metabolic Network Analysis, BMC Syst Biol., 6, S9, https://doi.org/10.1186/1752-0509-6-S2-S9, 2012.

Wang, W., Zhuo, L., Li, M., Liu, Y., and Wu, P.: The Effect of Development in Water-Saving Irrigation Techniques on SpatialTemporal Variations in Crop Water Footprint and Benchmarking, J. Hydrol., 577, 123916, https://doi.org/10.1016/j.jhydrol.2019.123916, 2019.

Xiao, D., Liu, D. L., Wang, B., Feng, P., Bai, H., and Tang, J.: Climate change impact on yields and water use of wheat and maize in the North China Plain under future climate change scenarios, Agr. Water Manage., 238, 106238, 2020.

Xu, Z., Chen, X., Wu, S. R., Gong, M., Du, Y., Wang, J., Li, Y., and Liu, J.: Spatial-temporal assessment of water footprint, water scarcity and crop water productivity in a major crop production region, J. Clean. Prod., 224, 375-383, https://doi.org/10.1016/j.jclepro.2019.03.108, 2019.

Yoon, P. R. and Choi, J. Y.: Efects of shift in growing season due to climate change on rice yield and crop water requirements, Paddy Water Environ., 18, 291-307, https://doi.org/10.1007/s10333-019-00782-7, 2020.

Zheng, J., Wang, W., Ding, Y., Liu, G., Xing, W., Cao, X., and Chen, D.: Assessment of climate change impact on the water footprint in rice production: Historical simulation and future projections at two representative rice cropping sites of China, Sci. Total Environ., 709, 136190, https://doi.org/10.1016/j.scitotenv.2019.136190, 2020.

Zhuo, L., Liu, Y., Yang, H., Hoekstra, A. Y., Liu, W., Cao, X., Wang, M., and Wu, P.: Water for maize for pigs for pork: An analysis of inter-provincial trade in China, Water Res., 166, 115074, https://doi.org/10.1016/j.watres.2019.115074, 2019.

Zhuo, L., Mekonnen, M. M., and Hoekstra, A. Y.: Benchmark levels for the consumptive water footprint of crop production for different environmental conditions: a case study for winter wheat in China, Hydrol. Earth Syst. Sci., 20, 4547-4559, https://doi.org/10.5194/hess-20-4547-2016, 2016a.

Zhuo, L., Mekonnen, M. M., Hoekstra, A. Y., and Wada, Y.: Inter- and intra-annual variation of water footprint of crops and blue water scarcity in the Yellow River basin (1961-2009), Adv. Water Resour., 87, 29-41, https://doi.org/10.1016/j.advwatres.2015.11.002, 2016b.

635 Zhuo, L., Mekonnen, M. M., and Hoekstra, A. Y.: Consumptive water footprint and virtual water trade scenarios for China With a focus on crop production, consumption and trade, Environ. Int., 94, 211-223, https://doi.org/10.1016/j.envint.2016.05.019, 2016c. 